\title{
実験的䨑肉剝離搔爬手術後の結合組織性 再付着の可能性について
}

\author{
木 村 喜 保 \\ 東京医科歯科大学歯学部第二歯科保存学教室 \\ （主任，指導：木下四郎教授） \\ (昭和 55 年 12 月 20 日受付)
}

\section{Possibility of Connective Tissue Reattachment following \\ Mucoperiosteal Flap Surgery with Full Gingival \\ Retention in Monkeys}

\author{
Yoshiyasu KIMURA \\ Department of Periodontology, School of Dentistry, \\ Tokyo Medical and Dental University \\ (Chief and Director: Prof. Shiro KINOSHITA)
}

The purpose of this study was to evaluate the height of connective tissue reattachment from the bone margin after flap operation in monkey. $3 \mathrm{~mm}$ or $1.5 \mathrm{~mm}$ of crestal bone was horizontally removed at buccal and interproximal areas, and root planing was carried out completely. For a histological land mark, a notch was prepared on the root surface at the bottom of bone defect. Ten weeks after operation, the monkey was sacrificed. The periodontal tissues of 40 teeth in two monkeys were observed histological1y. During ten weeks, efforts were made to keep oral hygiene as clean as possible.

The results which were obtained are as follows :

1) At molar areas which had slight gingival inflammation, connective tissue reattachment was clearly found. In the $3 \mathrm{~mm}$ bone defect group, it was $2.22 \mathrm{~mm}$ (S.D. 0.60), and in the $1.5 \mathrm{~mm}$ bone defect group it was $1.56 \mathrm{~mm}(\mathrm{~S}$. D. 0.70). The mean amount

本研究の要旨の一部は, 第 23 回春季日本歯周病学会総会, 第 45 回口腔病学会で発表した。 of new cementum in the $3 \mathrm{~mm}$ bone defect group was $1.06 \mathrm{~mm}$ (S.D. 0.54), and in the $1.5 \mathrm{~mm}$ bone defect group it was $1.00 \mathrm{~mm}$ (S. D. 0.80).

2) At incisor areas which showed moderate gingi val inflammation caused by narrow attached gingiva, good connective tissue reattachment could not be obtained. In such areas, epithelial proliferation to apical site was found, but it stopped at the area where new cementum formation occurred. The mean amount of connective tissue reattachment was 0.90 $\mathrm{mm}$ (S.D. 0.74) in the $3 \mathrm{~mm}$ bone defect group and $0.85 \mathrm{~mm}$ (S.D. 0.82) in the $1.5 \mathrm{~mm}$ bone defect group. The mean amount of new cementum was 0.61 $\mathrm{mm}$ (S.D. 0.39) in the $3 \mathrm{~mm}$ bone defect group and $0.49 \mathrm{~mm}$ (S. D. 0.39 ) in the $1.5 \mathrm{~mm}$ bone defect group.

3) The mean amount of alveolar bone loss at molar and incisor areas was $0.11 \mathrm{~mm}$ (S. D. 0.39) in the 3 $\mathrm{mm}$ bone defect group and $0.35 \mathrm{~mm}$ (S. D. 0.35 ) in the $1.5 \mathrm{~mm}$ bone defect group respectively. 


\section{I. 緒言}

骨縁下ポケットの形成を伴うような高度な骨吸収のみ られる歯周疾患に対し, 臨床的にはしばしば歯肉剝離搔 爬手術などの外科的治療法が行なわれる。これらの手術 方法は，歯肉弁を歯根面に再結合させる再付着あるいは 新付着という現象を利用して，手術創の治癒を計るもの である。

この再付着や新付着に関しては, 数多くの病理組織学 的研究が行なわれてきており, 口腔内に露出していた歯 根面には，歯肉弁が新付着しにくいことが示唆されてい $3^{1 \sim 6)}$ 。一方，未露出歯根面には再付着しやすく，実験的 歯肉剝離掻爬手術後に実際に再付着することが確認され ている7 18)。特にセメント質に付着している線維を残存 させた場合，すみやかに再付着するようである19 23)。

しかし, 実験的歯肉剥離搔爬手術後の再付着でも, 歯 根面をルートプレーニングしてセメント質および付着線 維を除去した歯根面では，上皮の根尖側増殖がしばしば 認められる。しかし，根尖側寄りの歯周組織では上皮の 根尖側増殖は停止し, 結合組織性再付着と新生セメント 質の添加が認められている9 12) 14115) 18)22)。このように 結 合組織性再付着は, 歯根面の状態に大きく左右されるこ とが明らかであるが，歯槽骨の状態も再付着に大きな影 響を及ぼすとされている。すなわち，残存壁数が多い骨 欠損例では骨の再生が起こりやすく，それと共に結合組 織性再付着も起こりやすいとされている ${ }^{2428)}$ 。一方, 水 平性骨欠損例では骨の再生が起こりにくいとされている 24) 25) 28) 29。乙かし水平性骨欠損の場合も結合組織性再付 着は,骨のレベルと何らかの関係があるように思われる。

また, 結合組織性再付着量について, Skillen ら ${ }^{30)}$ は $2 \mathrm{~mm}$ 程度起こるといい，Wilderman ら ${ }^{311}$ は平均 2.1 $\mathrm{mm}$, Marfino ら ${ }^{32)}$ は $1.5 \mathrm{~mm}$, Sugarman ${ }^{33)}$ は最長 3.2 $\mathrm{mm}$ 起こるとそれぞれ報告している。伊藤 ${ }^{10)}$ は骨頂部を $3 \sim 5 \mathrm{~mm}$ 削除した時, 上皮の根尖側増殖は $1.3 \mathrm{~mm}$ 以 下であり, Hiatt ら ${ }^{11)}$ は骨頂部を $8 \mathrm{~mm}$ 削除しても上皮 の根尖側増殖は観察されなかったと報告している。

以上のように結合組織性再付着に関する報告は数多く 見られるが，結合組織性再付着量は周囲の歯槽骨の状態 および歯根面の状態でまちまちなように思われ，歯槽骨 辺縁からどの程度の位置まで結合組織性再付着が起こり 得るかについては，十分に明らかにされていない。

そこで本実験では，歯槽骨辺縁と結合組織性再付着と の関係を知る目的で, 煩側と歯閒部に骨の再生が起こり
表 1 実験に用いたサルの性別, 体重，歯式，推定年齢

\begin{tabular}{c|c|c|c|c}
\hline & 性別 & 体重 $(\mathrm{kg})$ & 歯式 & 推定年粭 \\
\hline サル A & $\hat{\delta}$ & 9.0 & $\frac{8+8}{8+8}$ & 6 歳以上 \\
\hline サル B & 市 & 6.6 & $\frac{8+8}{8+8}$ & 6 歳以上 \\
\hline
\end{tabular}

表 2 処置方法

部位処置内容

\begin{tabular}{|c|c|c|c|}
\hline $\begin{array}{c}3 \mathrm{~mm} \\
\text { 骨削除群 }\end{array}$ & $\begin{array}{l}5 \sim 1 \\
5 \sim 1\end{array}$ & $\begin{array}{l}\text { 歯槽骨頂部の高さを } \\
3 \text { mm減じたもの }\end{array}$ & 20 歯 \\
\hline \multirow{2}{*}{$\begin{array}{c}1.5 \mathrm{~mm} \\
\text { 骨削除群 }\end{array}$} & $1 \sim 5$ & \multirow{2}{*}{$\begin{array}{l}\text { 歯槽骨頂部の高さを } \\
1.5 \mathrm{~mm} \text { 減じたもの }\end{array}$} & \multirow{2}{*}{ 20歯 } \\
\hline & $1 \sim 5$ & & \\
\hline \multirow{2}{*}{ コントロール } & $7 \mid 7$ & \multirow{2}{*}{ 未処置 } & \multirow{2}{*}{8 歯 } \\
\hline & \begin{tabular}{l|l}
7 & 7
\end{tabular} & & \\
\hline
\end{tabular}

にくいよう，水平に骨欠損を形成し，その 10 週目の歯 周組織の治療状態を観察した。

\section{II. 実験材料と実験方法}

\section{1. 実験材料}

実験動物には，全身所見および口腔内所見ともに異常の ない猿 2 頭を用いた。動物は別々のステンレス製ケージ に入れ，オリエンタル社製猿用固型飼料，リンゴ，キャ ベッ, 人参, 飲料水で飼育した。

本実験に用いた猿の性別，実験開始時における体重， 歯式，推定年齢73) は表 1 に示寸通りである。

麻醉剂としては動物用ケタラール 50 （三共株式会社 製）を体重 $1 \mathrm{~kg}$ あたり $0.3 \sim 0.6 \mathrm{~m} l$ 筋注した後, 手術部 位には歯科用キシロカイン(エピネフリン $0.0125 \mathrm{mg} / \mathrm{ml}$ 含有, 藤沢薬品工業株式会社製) を浸麻した。手術後, 感染予防を目的として 3 日間注射用ビクシリン（明治製 菓株式会社製)を筋注した。

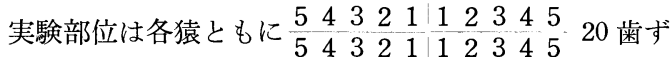

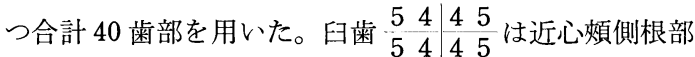
を使用した。これらの実験部位を表 2 で示すように $2 つ$

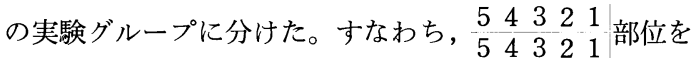
歯肉弁剝離後, 歯槽骨骨頂部から $3 \mathrm{~mm}$ 煩側と歯間部の 歯槽骨および歯根膜を水平に除去した群を $3 \mathrm{~mm}$ 骨削除 群, 同様に $\begin{array}{lllll}1 & 2 & 3 & 4 & 5 \\ 1 & 2 & 3 & 4 & 5\end{array}$ 部位で $1.5 \mathrm{~mm}$ 除去した群を 1.5 $\mathrm{mm}$ 骨削除群とした。 $\quad$\begin{tabular}{r|r|r}
7 & 7 \\
は
\end{tabular} 未処置のコントロール群 とした。 


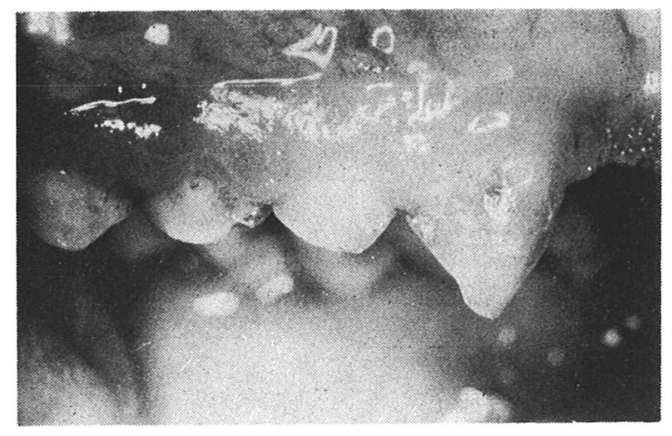

(3 mm 骨削除群)

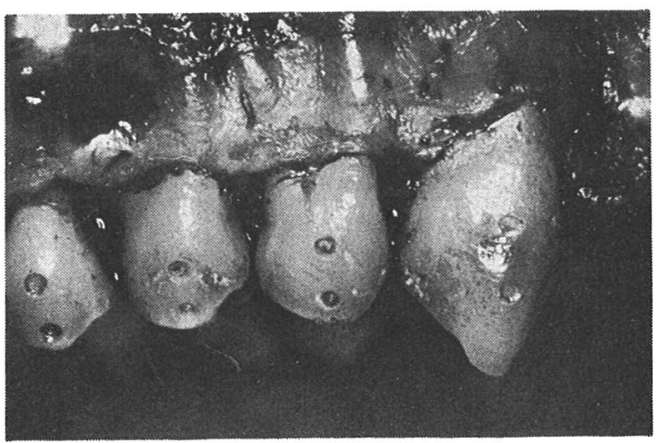

（3 mm 骨削除群）
図 $1 \mathrm{~b}$ 歯肉を剝離したところ

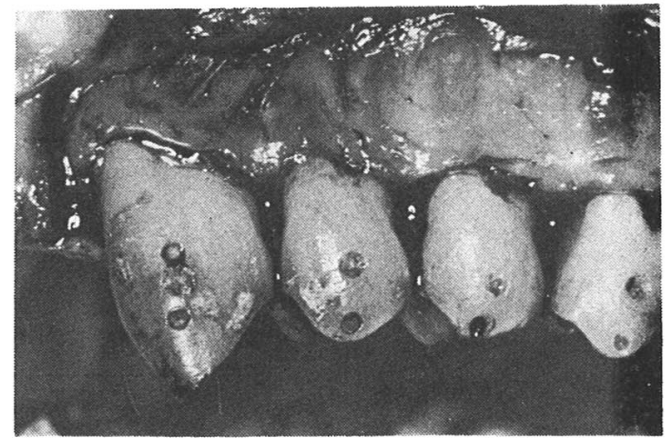

(1.5 mm 骨削除群)
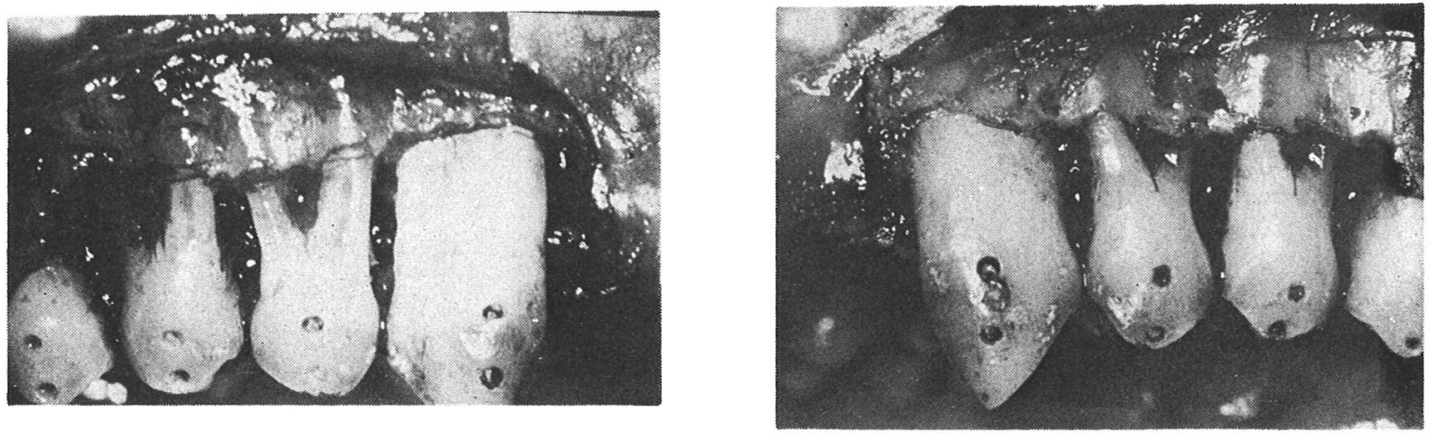

(3 mm 骨削除群)

図 1 c 骨頂部削除後

(1. $5 \mathrm{~mm}$ 骨削除群)

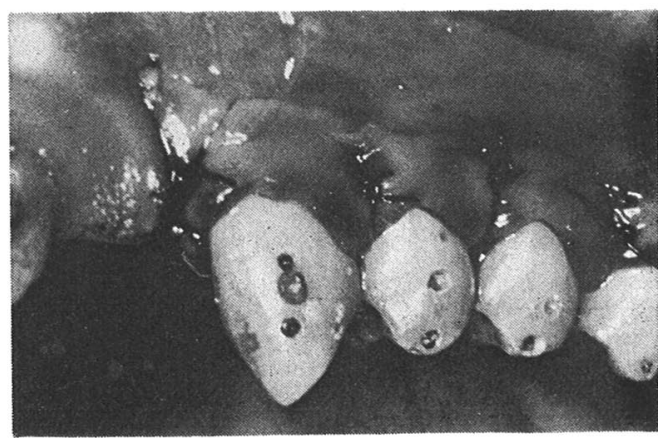

(3 mm 骨削除群)

図 $1 \mathrm{~d}$ 縫合後

(1.5 mm 骨削除群)

図1 骨削除方法 (実際例) 


\section{2. 実験方法}

\section{1) 歯槽骨欠損の形成方法}

実験群の被験歯の煩側歯肉弁を替刃 カー社製）で，歯肉溝底部から骨頂部まで切開を加えた 後, 骨膜剥離子で骨膜と共に剥離した（図 $1 \mathrm{~b}$ )。煩側と 歯間部の歯槽骨を水平に 骨頂部から $3 \mathrm{~mm}$ あるいは 1.5 $\mathrm{mm}$ 削除した (図 $1 \mathrm{C}$ )。煩側の骨は骨ノミおよび歯科用 チゼルを用いて除去した。歯間部の骨は, 最初骨ノミと 歯科用チゼルを用いて除去し，細部は $\$ 2$, \$3 のラウン ドバーを用いて生食水を注水しながら, 図 $2 \mathrm{a}, 2 \mathrm{~b}$ の ように削除した。骨欠損形成の際, 舌側の歯肉弁は剝離 せず，図 $2 \mathrm{~b}$ で示すように舌側の近心隅角から遠心隅角 までの骨は除去しなかった。

\section{2）歯根面の処置方法}

歯槽骨を除去して露出した歯根面は，煩側近心隅角か ら遠心隅角まで徹底したルートプレーニングを 3 回ずつ 行ない, 歯根面に残存している付着線維およびセメント 質を完全に除去した。歯槽骨を除去した高さの煩側近心 隅角から，遠心隅角までの歯根面にチゼルでノッチをつ けた。これを病理組織学的計測のための定点として使用 した。以後, 臨床的観察および病理組織学的観察は煩側, 特に中央部のみとして歯間部は観察に供しなかった。

以上の操作を行なった後, 歯肉弁はなるべく元の位置 にもどし，剝離しなかった舌側の歯肉で懸垂するように し, さらに歯根面に密着させて歯間部でナイロン系を用 いて単純結紮した (図 1 d)。

\section{3. 実験期間}

タイムスケジュールは表 3 に示す通りである。骨欠損 を形成する時を原点とした。2 週前より, 口腔清掃とし て週 2 回のスクラッビング法によるブラッシングと週 1 回のスケーリングを行なった。さらに新しい試みとし て, クロールヘキシジン $0.05 \%$ 水溶液を飲料水として 与えた。以上の口腔清掃を 10 週目まで続けた。

術後 1 週から 2 週の間に抜糸を行なった。食物による 歯肉への異常な外力を防ぐ目的で, 5 週目まで軟飼料を 与え, 以後 10 週目までは普通飼料を与えた。また, 野 菜と果実は術直後から 10 週目まで $3 \mathrm{~mm}$ 幅に輪切りに して与えた。術後 10 週目に屠殺した。

\section{4. 観察方法}

\section{1) 臨床的観察}

骨欠損形成の手術前後および実験期間を通じて，口腔 内のカラー写真撮影, 歯肉辺縁の退縮変化, ポケットの
深さ，体重の測定を行なった。歯肉辺縁の退縮変化と歯 槽骨骨頂部削除前後の骨頂部高さの臨床的計測は, Tavtigian $^{34)}$ の方法を改良して行なった。すなわち，歯 冠中央の歯肉辺縁上約 $1 \mathrm{~mm}$ の所に象牙質に達する定点 をカーバイトバーと $\$ 1 / 2$ ラウンドバーで形成し，さら に歯軸に平行でその点より $2 \mathrm{~mm}$ 歯冠側部にもう 1 点形 成した。その 2 点を定点の足場として, 図 3 のようにコ ンパスで各組織計測点まで計り，その距離をさらに $1 / 20$ $\mathrm{mm}$ 副尺付ノギスで計測した。ポケット測定は術前と術 後 5 週目に行なった。

\section{2) 病理組織学的観察}

動物を屠殺後，直ちに上下顎骨をとりはずし，10\% 中性ホルマリンで固定した。Plank \& Rychlo 液で脱灰 後, パラフィン包埋し, 歯軸に平行に切るように考慮し た上で, 煩舌方向に約 $10 \mu$ の厚さで連続切片を作製し, ヘマトキシリンーエオジン重染色を施した。以上のよう に作製した連続切片中から，臨床的計測を行なった煩側 中央部を中心として前後 60 枚の切片を取り出し,さらに その中から等間隔に 5 枚選び, 顕微鏡下で観察および計 測を行なった。計測は 20 倍で行なった。

測定項目は図 4 に示す通り，1. 再生した歯槽 骨の高 さ，2. 再生した新生セメント質の長さ，3. 結合組織性 再付着の長さ, 4. ノッチ底部から歯肉辺縁までの長さで ある。本実験での結合組織性再付着とは，ノッチ底部か ら上皮の根尖側増殖の停止している位置までとし，新生 セメント質の再生とは, 100 倍レベルで明らかに添加の 認められるものとした。

\section{III. 結 果}

\section{1. 全身所見}

体重変化は図 5 に示す通りである。骨削除手術後, 多 少餌の摂取が少なくなり体重の減少が見られたが，体重 の減少量は $10 \%$ 以下であった。

口腔清掃法の 1 つとして，クロールヘキシジン 0.05 \% 水溶液を飲料水として与えたが, 実験期間を通して飲 水の拒否および全身的異常は観察されなかった。1日の クロールヘキシジン $0.05 \%$ 水溶液の摂取量の平均は, $\mathrm{A}$ サル $420 \mathrm{~m} l, \mathrm{~B}$ サル $180 \mathrm{ml}$ で, 主に朝と食餌中に飲水す るようであった。

\section{2. 歯周組織所見 \\ 1）口腔内所見}

術前 2 週目より口腔清掃を行ない，骨欠損形成手術時 


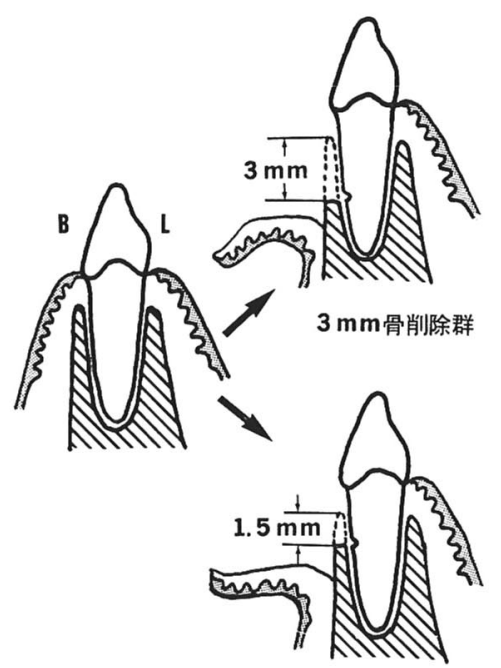

$1.5 \mathrm{~mm}$ 骨削除群

歯槽骨の削除方法（烦乱断面）

図 2 a 歯槽,骨の削除方法 (煩舌断面) $\mathrm{L}$

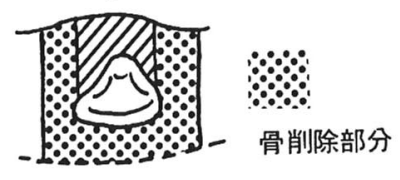

B

図 2 b 歯槽骨の削除方法 (咬合面観)

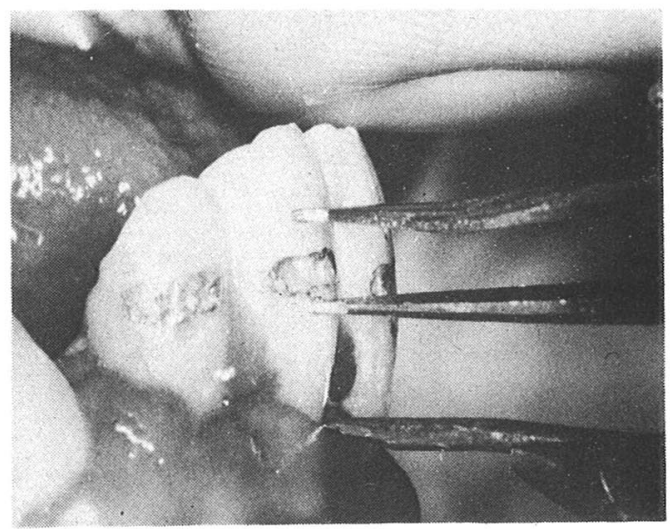

図 3 臨床的計測方法

歯肉辺縁までの距離を計测しているところ

にはほぼ炎症のない状態になった。しかし前歯部には弱 い炎症発赤が残っていた。

手術後，外科的侵襲による炎症発赤が見られたが，1 週以内に消炎し臨床的には良好な治癒を示し, 全実験部 位で感染などの事故は認められなかった。
表 3 実験計画

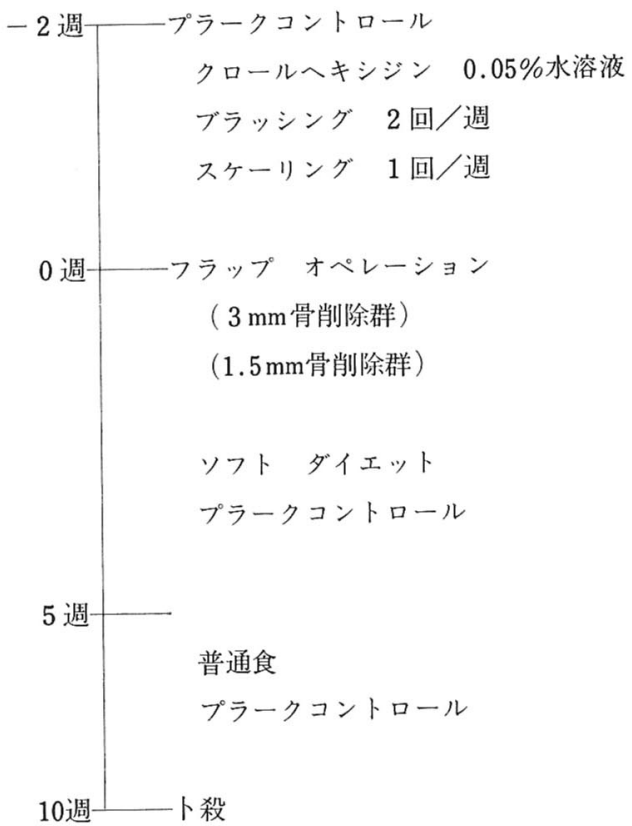

領钽鏡での測定項目

1. 再生した菌槽骨の長さ

2. 再生した新生セメント質の長さ

3. 結合組織性再付着の長さ

4. ノッチ底部から曾肉辺縁までの長さ

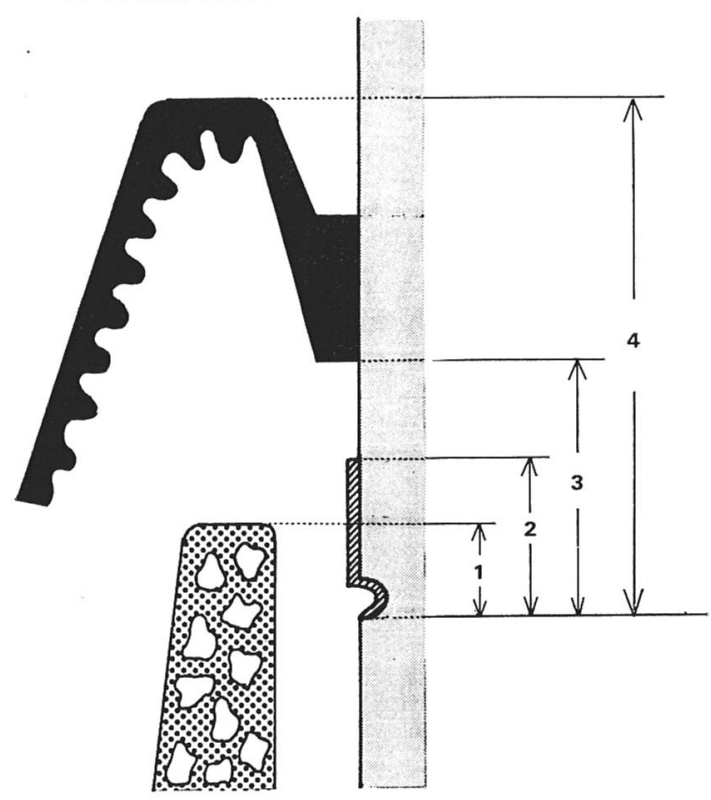

図 4 
治痖期閒を通して, 前歯部では一般に口腔前庭が 浅 く, 付着歯肉幅が狭くまた小带の付着位置が高いなどの 理由により，歯肉弁の歯根面への密着はやや不良で，ま たプラーク，歯石などがやや沈着し炎症が認められた (図 6a)。且歯部では歯肉弁の歯根面への密着は良好でプ

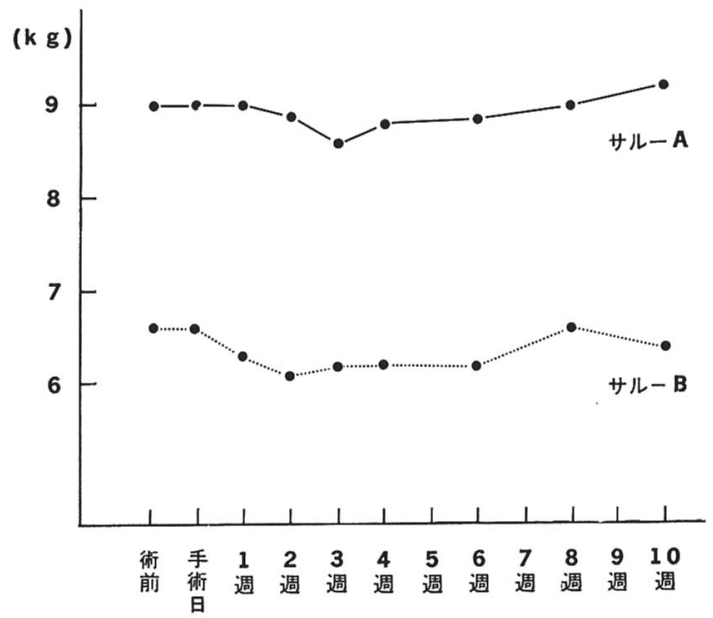

図 5 体重変化

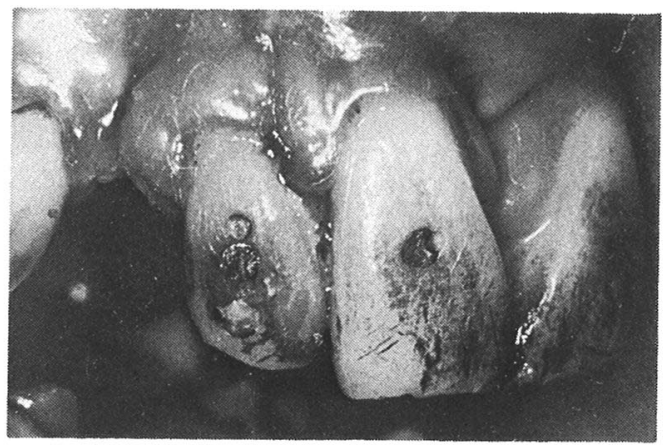

(3 mm 骨削除群)

図 6 a

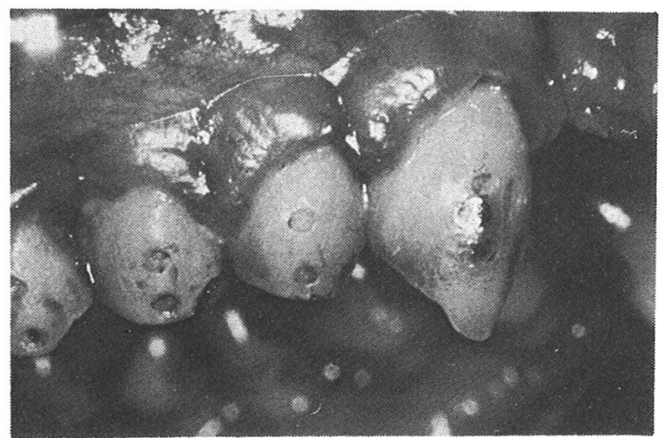

(3 mm 骨削除群)
ラーク，歯石の沈着もほとんどなく，軽度の炎症が認め られるにすぎなかった (図 6 b)。

$1.5 \mathrm{~mm}$ 骨削除群の白歯 1 歯は, 骨欠損形成時に拔歯 したため, 以降結果から除外した。

\section{2）歯肉辺縁の変化}

歯冠部につけた臨床的計測のための定点から歯肉辺縁 までの距離を術前, 縫合後, $1,2,3,4,6,8,10$ 週に 計 測した。術前の歯肉辺縁の位置を退縮量 0 として, 以下 10 週目までの退縮量を経時的に図示したのが図 7 a (3 $\mathrm{mm}$ 骨削除群), 図 $7 \mathrm{~b}$ ( $1.5 \mathrm{~mm}$ 骨削除群) である。剝 離歯肉弁縫合時, 舌側の剝離しなかった歯肉弁を支持と して，なるべく元の位置に戻すように衰引縫合したが， 縫合直後 $3 \mathrm{~mm}$ 骨削除群, $1.5 \mathrm{~mm}$ 骨削除群でそれぞ れ $0.93 \mathrm{~mm}$ (S.D. 0.75) $0.73 \mathrm{~mm}$ (S.D. 0.70)の歯肉 退縮が起こった。しかし，両群の間で退縮量に有意差は なかった $(\mathrm{P}>0.05)$ 。治療が進行するにつれ, 両群とも に歯肉辺縁の退縮量が増加し， 2 週目では $3 \mathrm{~mm}$ 骨削除 群, $1.5 \mathrm{~mm}$ 骨削除群でそれぞれ $2.06 \mathrm{~mm}$ (S. D. 0.75), $1.31 \mathrm{~mm}$ (S.D. 0.73) となり, 両群の間に有意差を示 した $(\mathrm{P}<0.05)$ 。3 週以降になると両群ともほとんど歯

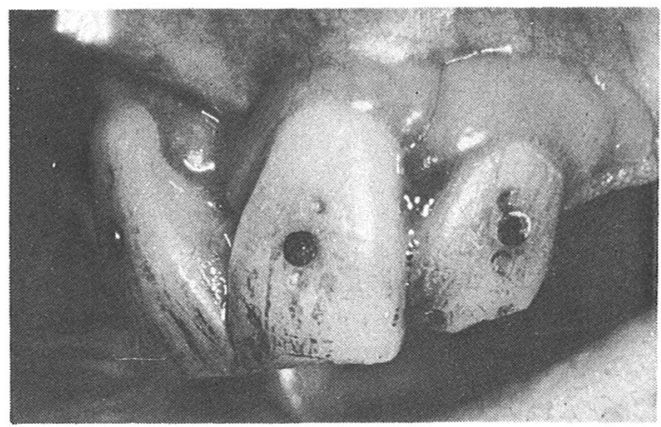

前歯

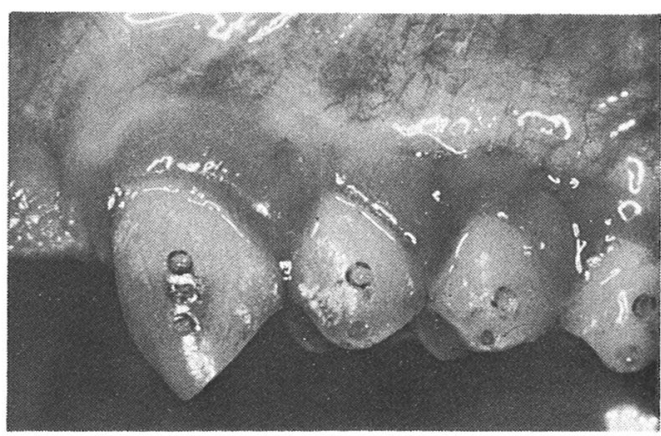

(1.5 mm 骨削除群)

図 6 b 延歯

図 6 術後 10 週の口腔内写真 


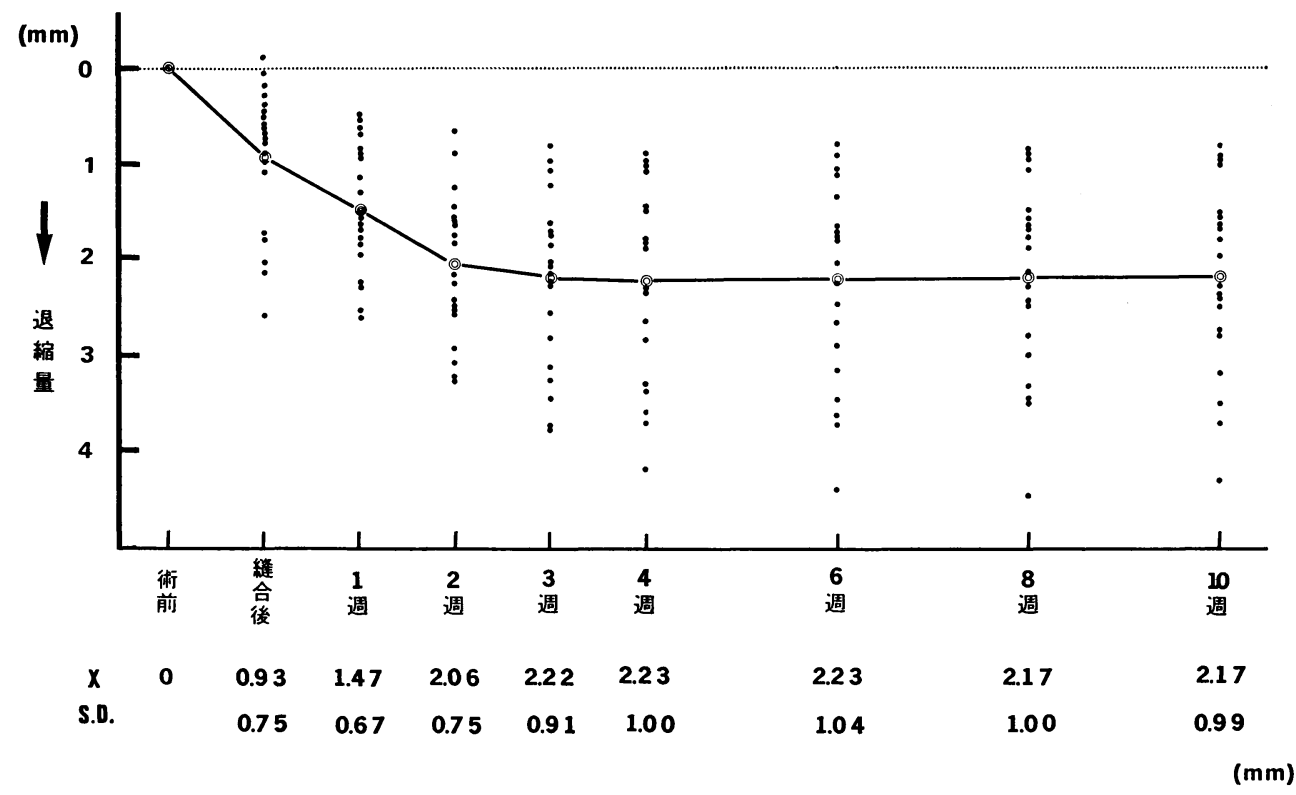

図 7 a 歯肉辺縁の退縮量 (3 mm 骨削除群)

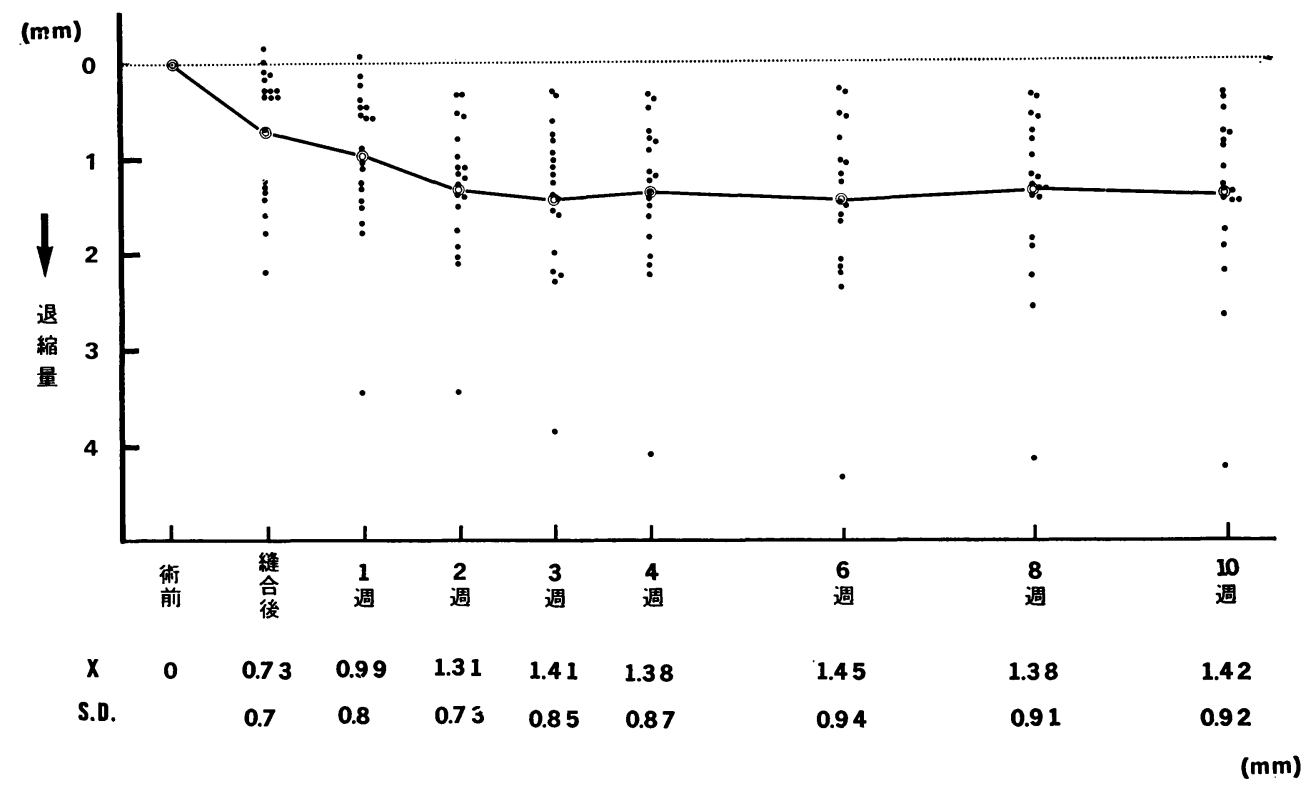

図 $7 \mathrm{~b}$ 歯肉辺縁の退縮量 (1.5 mm 骨削除群)

肉退縮を示さず, 3 週までに起こった歯肉退縮量を 10 週 まで維持していた。3 週から 10 週までの歯肉辺縁退縮量 にも両群の間で有意差を示した $(\mathrm{P}<0.05)$ 。

一方，骨削除を行なわなかったコントロール群では， 歯肉辺縁の変化はほとんど認められなかった。

\section{3）歯肉溝の深さの変化}

$3 \mathrm{~mm}$ 骨削除群, $1.5 \mathrm{~mm}$ 骨削除群の術前における歯 肉溝の深さの平均はそれぞれ，1.80 mm (S.D. 0.55), $1.80 \mathrm{~mm}$ (S.D. 0.64) であり, 術後 5 週目の平均はそれ ぞれ $1.66 \mathrm{~mm}$ (S. D. 0.65), $1.69 \mathrm{~mm}$ (S.D. 0.79) だっ た。個々の歯の歯肉溝の深さは図 16 に示した。 


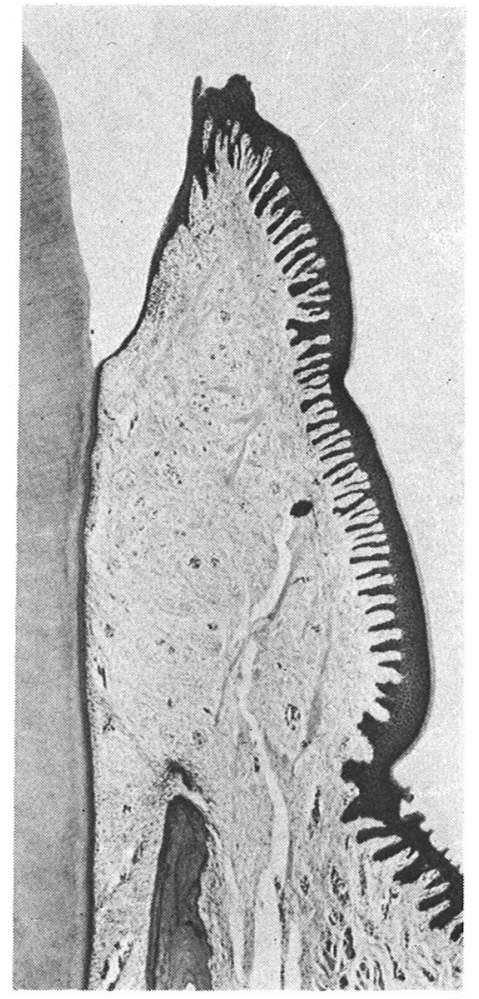

図 8 コントロール群 $\times 10, \mathrm{H}-\mathrm{E}$ 染色

歯槽骨頂上の結合組織性付着の平 均は $0.67 \mathrm{~mm}$.

歯槽骨頂部から歯肉辺縁までの長 さの平均は $2.08 \mathrm{~mm}$.

\section{3. 病理組織学的所見}

1) コントロール (図 8)

歯槽骨頂上のセメント質は，セメントーエナメル境ま で一様の厚さで存在し，そのセメント質に歯肉線維が放 射状に埋大し，機能的配列を示していた。歯肉溝上皮の 根尖端はセメントーエナメル境あるいはそれよりやや下 がった位置にあった。歯肉溝上皮に沿う粘膜下組織に は, ごく軽度の炎症性細胞浸潤が認められた。

\section{2) $3 \mathrm{~mm}$ 骨削除群臼歯 (8 歯)}

実験群の全歯で，ルートプレーニングした根面は旧セ メント質が除去されていた。

ルートプレーニングした象牙質面上にかなり長い結合 組織性再付着が認められた。しかしコラーゲン線維は根 面に平行に密に配列していた。

8 歯中 7 歯でほとんど上皮の根尖側増殖は認められな かった (図 $9 \mathrm{a}, 10 \mathrm{a}$ )。しかし 8 歯中 1 歯で根尖側増殖を 認めた（図 11）。この 1 歯では歯周ポケット底部と思わ

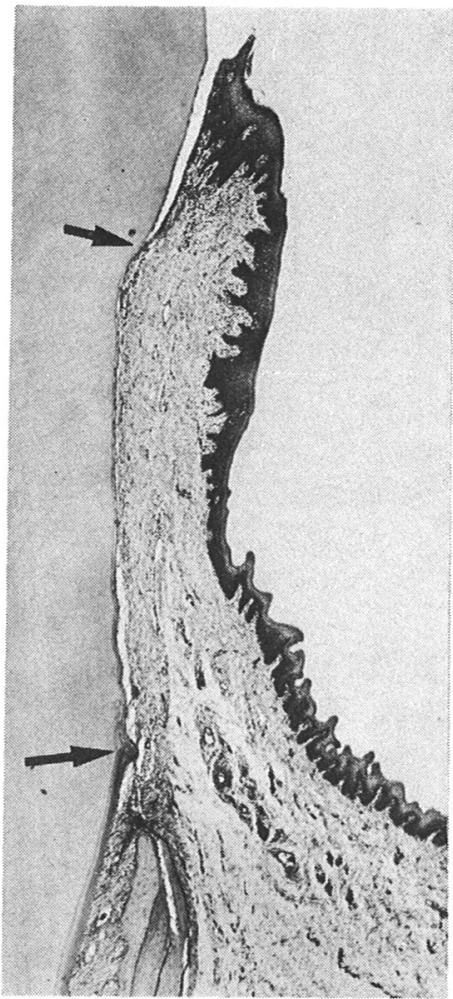

図 9 a $3 \mathrm{~mm}$ 骨削除群臼歯 新生セメント質再生の良好例 (8 歯 中 2 歯)。ルートプレーニングした 歯根面は旧セメント質が除去されて いる。結合組織性再付着は約 $2 \mathrm{~mm}$, 上皮の根尖側増殖 (上の矢印) は $0.8 \mathrm{~mm}$ 認められる。歯槽骨頂部は 歯槽骨削除断端)ッチ (下の矢印) より $0.3 \mathrm{~mm}$ 根尖側に位置してい る。 $\times 10, \mathrm{H}-\mathrm{E}$ 染色

れる固有層部に著しい炎症性細胞浸潤が認められた。し かし新生セメント質の再生は良好で, この再生部で上皮 の根尖側増殖を阻止しているようだった。

上皮の根尖側増殖を認めなかった 7 歯中 2 歯では, 新 生セメント質の再生が良好に認められた（図 9 a)。根尖 側部では厚い新生セメント質の再生が認められ, ルート プレーニングした象牙質面は比較的平滑で, 表在性の歯 根吸収は著明ではなかった（図 9 b)。歯冠側に向うにつ れて, その厚みは減少するが, 新生セメント質の添加は 一様に認められ (図 $9 \mathrm{C}$ ), 上皮直下までその状態で添加 されていた(図 9 d)。

一方, 7 歯中 5 歯では上皮付着下まで新生セメント質 の添加は認められず，途中で中断していた（図 10 a)。 


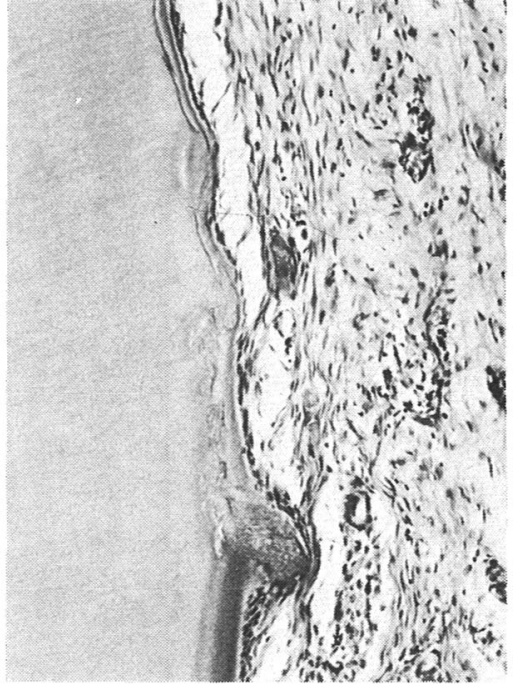

図 9b 図 $9 \mathrm{a}$ の強拡大 根尖側部 $\times 100, \mathrm{H}-\mathrm{E}$ 染色

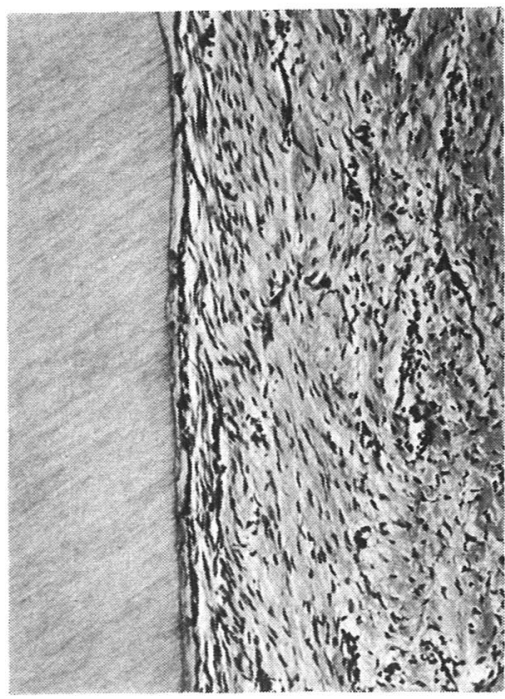

図 $9 \mathrm{c}$ 図 $9 \mathrm{a}$ の強拡大 中間部 $\times 100, H-E$ 染色

根尖側部で厚みを持っていた新生セメント質（図 $10 \mathrm{~b}$ ) は歯冠側に向うにつれ, その厚みを減少し,さらに歯冠側 部では表在性の吸収窩部分にのみ少量の添加が認められ るにすぎなかった。さらに歯冠則部では新生セメント質 の添加は認められず, 線維芽細胞様細胞が根表面に密接 していた。細胞に面する歯根表面では，わずかに表在性 の吸収が認められるものもあった（図 $10 \mathrm{C}, 10 \mathrm{~d}$ )。この ような細胞の密接があり, その囲りに結合組織線維が根

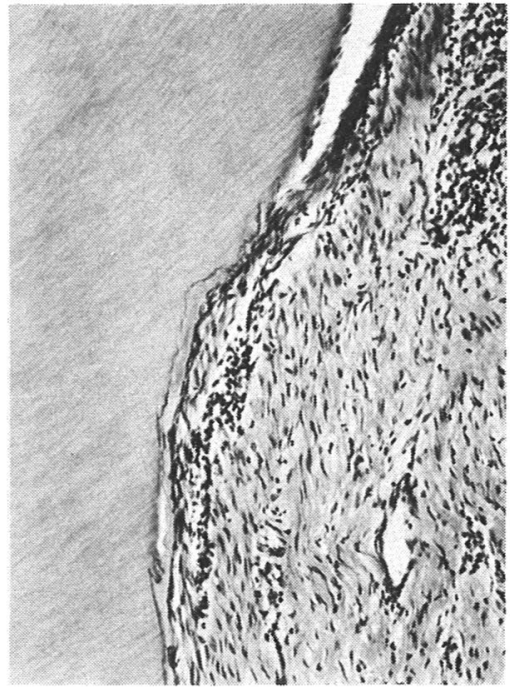

図 9d 図9aの強拡大 上皮付着直下部 $\times 100, \mathrm{H}-\mathrm{E}$ 染色

面に平行に配列していた。またこのような細胞密接部 で上皮の根尖側増殖を阻止しているようであった。

歯槽骨は, 削除断端の位置から著明な吸収も再生も示 していなかった。

3) $1.5 \mathrm{~mm}$ 骨削除群臼歯 (7 歯)

7 歯中 4 歯 で軽度の上皮の根尖側増殖が 認められた (図 12 a)。また 7 歯中 1 歯では，上皮の根尖側増殖が認 められ, 結合組織性再付着の長さは $1 \mathrm{~mm}$ 以下であった。 一方, 7 歯中 2 歯では, 上皮の根尖側増殖はほとんど認 められなかった。

新生セメント質の再生は 7 歯中 7 歯で不良で，歯根表 面は 7 歯中 7 歯で表在性の吸収を認め, その吸収窩に新 生セメント質の添加が認められた。

一般的には，根尖側部でごく薄い新生セメント質の添 加が認められ (図 $12 \mathrm{~b}$ ), さらに歯冠側部では表在性の吸 収窩部分にのみ少量の添加が認められ (図 $12 \mathrm{C}$ ), さらに 歯冠側部では新生セメント質の添加が認められず, 細胞 が歯根面に密接していた（図 $12 \mathrm{~d}$ )。

歯槽骨骨頂部はわずかに根尖側に吸収されていた。

4) $3 \mathrm{~mm}$ および $1.5 \mathrm{~mm}$ 骨削除群前歯 (22 歯)

$\mathrm{A}$ サルの3|3の 2 歯は組織学的定点であるノッチ不備 のため, 組織学的結果から除外した。

$3 \mathrm{~mm}$ および $1.5 \mathrm{~mm}$ 骨削除群の前歯の病理組織像は 両群で特別な違いは認められなかった。

22 歯中 15 歯で, 歯肉溝上皮に沿う固有層部および上 皮付着直下に中等度の炎症性細胞浸潤が認められた。歯 


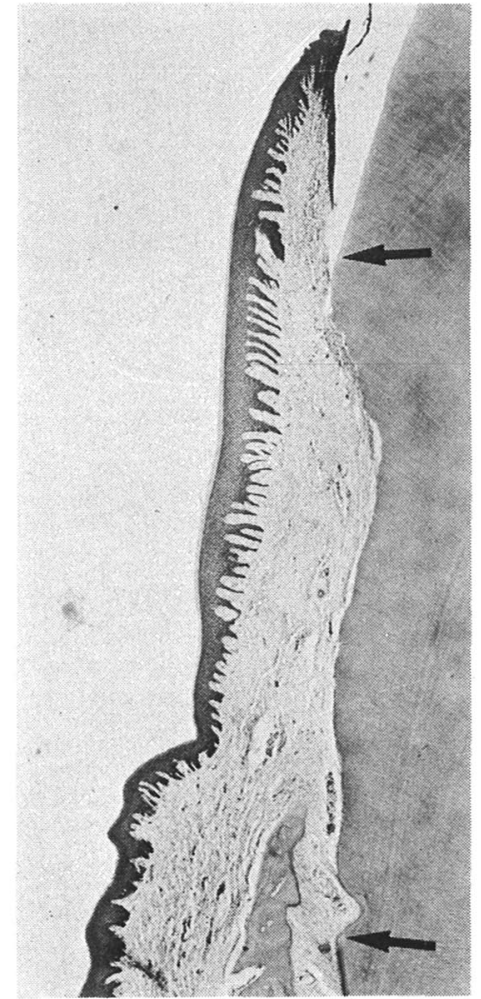

図 10 a $3 \mathrm{~mm}$ 骨削除群臼歯 新生セメント質再生不良例（8 歯中 5 歯)。結合組織性再付着は約 $3.2 \mathrm{~mm}$ (最長例), 上皮の根尖側增殖（上の 矢印) は約 $0.9 \mathrm{~mm}$ 認められる。歯槽 骨頂部法，骨削除断端ノッチ（下の矢 印) より $0.69 \mathrm{~mm}$ 歯冠側に位置して いる。 $\times 10, \mathrm{H}-\mathrm{E}$ 染色

肉溝上皮は肥厚し, 根尖側増殖および側方増殖が著しか った(図 $13 \mathrm{a}, 14 \mathrm{a}$ )。

しかし根尖側部では新生セメント質の添加を伴った結 合組織性再付着が認められた (22 歯中 22 歯)。新生セメ ント質にはかなり密な結合組織線維が機能的配列を示し て埋入していた（図 $13 \mathrm{~b}$, 図 $14 \mathrm{~b}$ )。このような部で, 上 皮の根尖側増殖が停止していた。

22 歯中 7 歯では, 上皮の根尖側増殖は軽度で $1 \mathrm{~mm}$ 以 上の結合組織性再付着が認められた（図 15)。

\section{4. 組織学的計測の結果}

表 4 は, 全歯の 1. 再生した歯槽骨の長さ, 2. 再生した 新生セメント質の長さ, 3. 結合組織性再付着の長さ, 4. ノッチ底部から歯肉辺縁までの長さ, の組織学的計測值

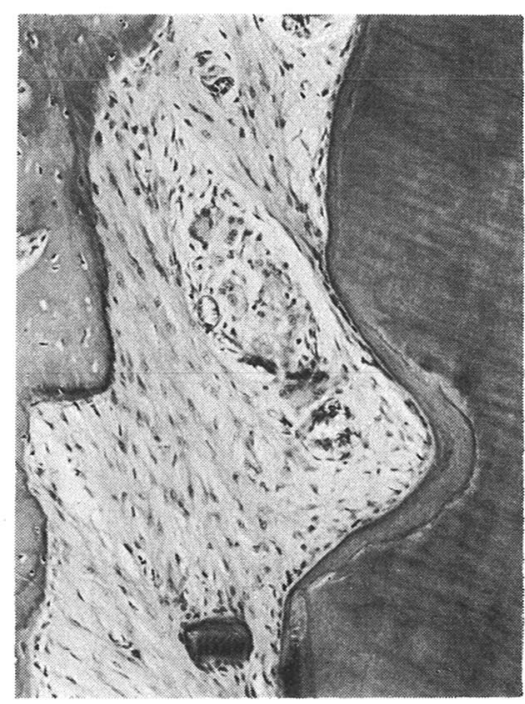

図 $10 \mathrm{~b}$ 図 $10 \mathrm{a}$ の強拡大 根尖側部 $\times 100, \mathrm{H}-\mathrm{E}$ 染色

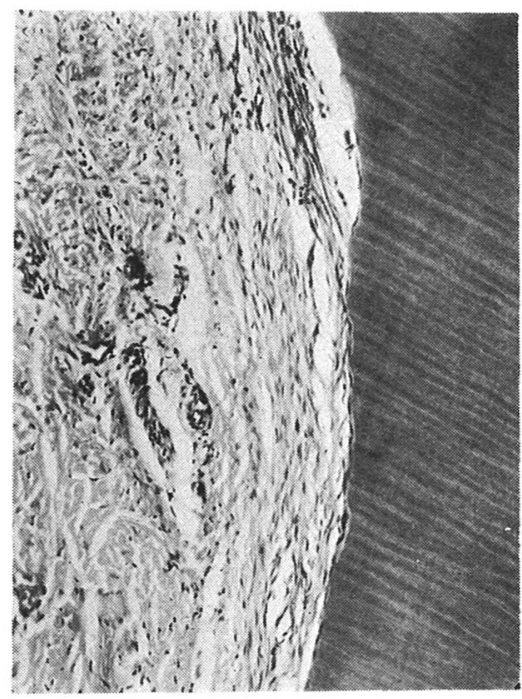

図 $10 \mathrm{c}$ 図 $10 \mathrm{a}$ の強拡大 中間部 $\times 100, \mathrm{H}-\mathrm{E}$ 染色

を表わしたものである。図 16 は表 4 を図式化したもの である。

1）歯槽骨の再生

$3 \mathrm{~mm}$ 骨削除群, $1.5 \mathrm{~mm}$ 骨削除群の再生した歯槽骨 の長さの平均はそれぞれ，-0.11 mm (S.D. 0.39), -0.35 mm (S.D. 0.35) で両群ともわずかの骨吸収を示 した。しかし $3 \mathrm{~mm}$ 骨削除群の下顎では, 10 歯中 6 歯で 骨の再生が認められ, 他の部位と比較するとやや良好だ った。 


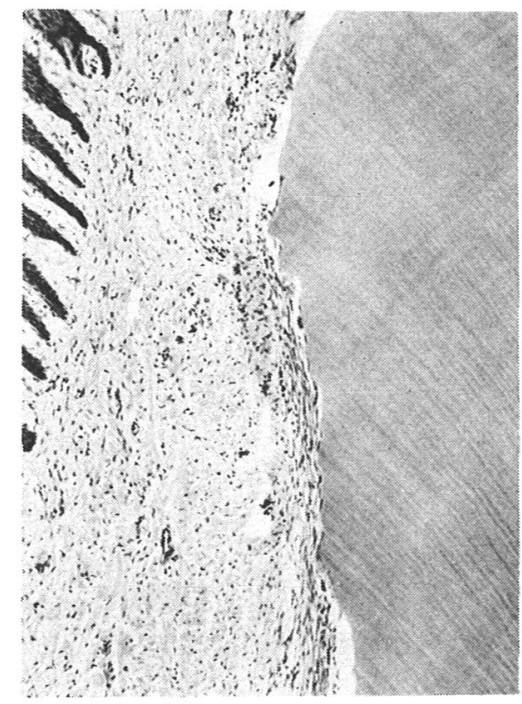

図 $10 \mathrm{~d}$ 図 $10 \mathrm{a}$ の強拡大 上皮付着直下部 $\times 100, \mathrm{H}-\mathrm{E}$ 染色

\section{2）新生セメント質の再生}

$3 \mathrm{~mm}$ 骨削除群, $1.5 \mathrm{~mm}$ 骨削除群の再生した新生セ メント質の長さの平均はそれぞれ，0.8 mm (S.D. 0.5), $0.69 \mathrm{~mm}$ (S.D. 0.62) で，わずかに $3 \mathrm{~mm}$ 骨削除群の方 が再生の長さが大きかったが，両群の間に有意差はなか

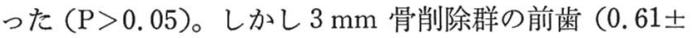
$0.39 \mathrm{~mm})$ と自歯 $(1.06 \pm 0.54 \mathrm{~mm})$ との間で有意差が あり $(\mathrm{P}<0.05), 1.5 \mathrm{~mm}$ 骨削除群でも鼠歯の方が前歯 より再生の長さが大きい傾向が認められた。

\section{3）結合組織性再付着の長さ}

$3 \mathrm{~mm}$ 骨削除群, $1.5 \mathrm{~mm}$ 骨削除群の結合組織性再付 着の長さの平均はそれぞれ, $1.46 \mathrm{~mm}$ (S.D. 0.95), 1.13 mm (S.D. 0.83) で，両群の間に有意差はなかった (P> 0.05) が $3 \mathrm{~mm}$ 骨削除群の方がわずかに結合組織性再付 着の長さが大きい傾向が認められた。 $3 \mathrm{~mm}$ 骨削除群の 前歯 $(0.9 \pm 0.74 \mathrm{~mm})$ と臼歯 $(2.22 \pm 0.6 \mathrm{~mm})$ との間 に有意差が認められた $(\mathrm{P}<0.005)$ 。

$1.5 \mathrm{~mm}$ 骨削除群でも且歯 $(1.56 \pm 0.70 \mathrm{~mm})$ の方が, 前歯 $(0.85 \pm 0.82 \mathrm{~mm})$ より再付着の長さが大きい傾向 が認められた。また，両群の臼歯の結合組織性再付着の 長さを比較すると， $3 \mathrm{~mm}$ 骨削除群 (2.22 $20.60 \mathrm{~mm}$ ) の方が $1.5 \mathrm{~mm}$ 骨削除群 (1.56士0.70 mm) より再付着 の長さが大きい傾向が認められた。

4)ノッチから歯肉辺縁までの長さ

$3 \mathrm{~mm}$ 骨削除群, $1.5 \mathrm{~mm}$ 骨削除群のノッチから歯肉 辺縁までの長さの平均はそれぞれ，3. $31 \mathrm{~mm}$ (S.D.

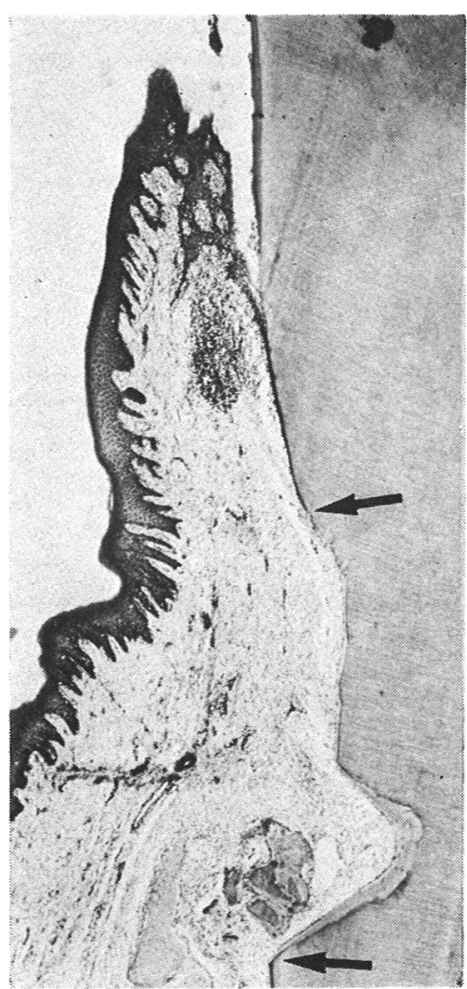

図 $113 \mathrm{~mm}$ 骨削除群臼歯

$3 \mathrm{~mm}$ 骨削除群臼歯では唯一の上 皮の根尖側増殖を認めた例であ る。結合組織性再付着は約 1.4 $\mathrm{mm}$, 上皮の根尖側増殖（上の矢 印) は約 $2 \mathrm{~mm}$ 認められる。歯槽 骨頂部は，骨削除断端ノッチ（下 の矢印) より $0.46 \mathrm{~mm}$ 歯冠側に 位置している。 $\times 10, \mathrm{H}-\mathrm{E}$ 染色

0.6), $2.86 \mathrm{~mm}$ (S.D.0.68) で，両群の間に有意差が 認められた $(\mathrm{P}<0.05)$ 。

しかし，歯槽骨骨頂部から歯肉辺縁までの長さは，3 $\mathrm{mm}$ 骨削除群では $3.46 \mathrm{~mm}$ (S.D. 0.68), $1.5 \mathrm{~mm}$ 骨削 除群では $3.22 \mathrm{~mm}$ (S.D. 0.61) となり, 両群の間に有意 差がなかった（P>0.05）。

5）コントロール群の計測值。

$\frac{7 \mid 7}{7}$ の合計 8 歯から平均值を求めた。骨頂上の結合組 織性付着の長さは, $0.67 \mathrm{~mm}$ (S.D. 0.17), 歯槽骨骨頂部 から歯肉辺縁までの長さは $2.08 \mathrm{~mm}$ (S.D. 0.39) だっ た。 


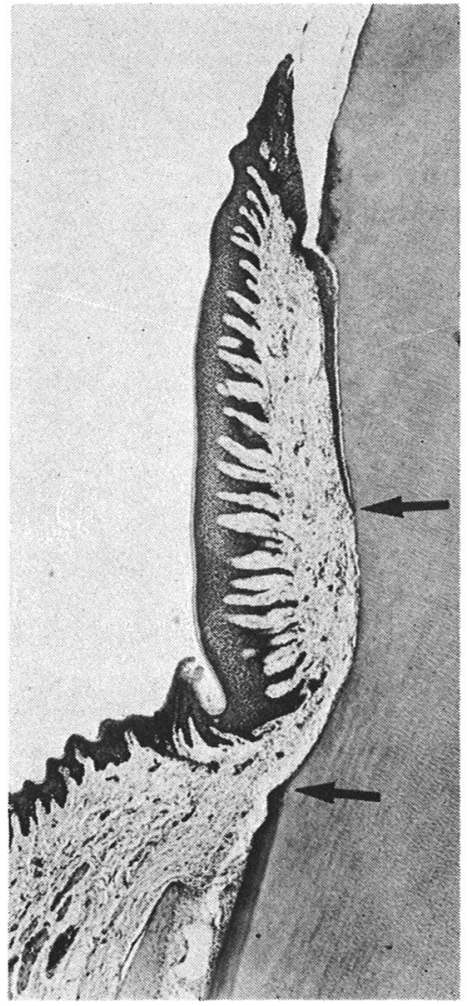

図 $12 \mathrm{a} \quad 1.5 \mathrm{~mm}$ 骨削除群臼歯 $3 \mathrm{~mm}$ 骨削除群臼歯と比較すると 上皮の根尖側増殖がやや多い(7 歯中 4 歯)。この例では, 結合組織 性再付着は $1.3 \mathrm{~mm}$, 上皮の根尖 側増殖 (上の矢印) は $1.4 \mathrm{~mm}$ 認 められる。歯槽骨頂部は, 骨削除 断端ノッチ (下の矢印) より 0.4 $\mathrm{mm}$ 根尖側に位置している。

$\times 10, \mathrm{H}-\mathrm{E}$ 染色

\section{IV. 考察}

\section{1. 実験方法について}

1） セメント質のルートプレーニングについて 本実験では外科的に露出した歯根面を徹底的にルート プレーニングし, セメント質およびその付着線維を除去 した。

一般に露出セメント質は口腔環境から影響を受け，種 々の変化を起こしていると言われている ${ }^{35)}$ 。脱灰凍結切

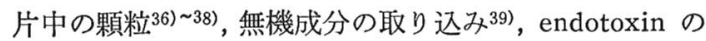
吸着40)などが観察されている。このような変化は露出セ メント質の表層に限られるとも深層にまで及んでいると

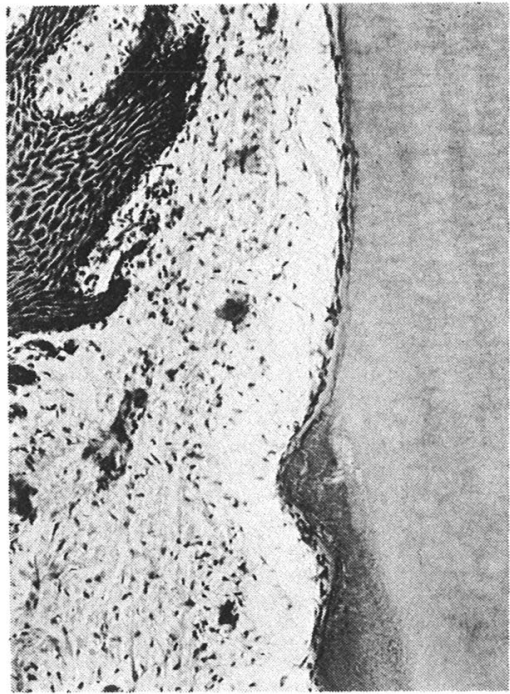

図 $12 \mathrm{~b}$ 図 $12 \mathrm{a}$ の強桩大 根尖側部 $\times 100, \mathrm{H}-\mathrm{E}$ 染色

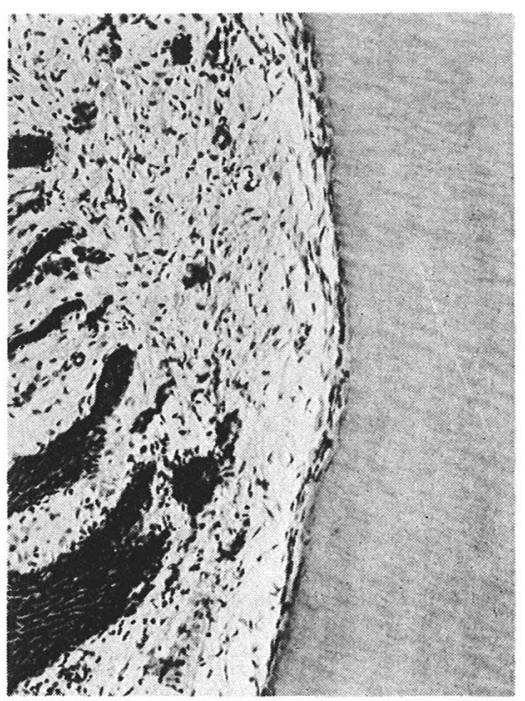

図 $12 \mathrm{c}$ 図 $12 \mathrm{a}$ の強拡大 中間部 $\times 100, \mathrm{H}-\mathrm{E}$ 染色

も言われている39)41)。しかし徹底的なルートプレーニン グ (深さ $1 \mathrm{~mm}$ 程度) で正常歯根面が得られることが確 認されている42)43)。

そこで，本実験でも以上の説に従い，未露出歯根面で はあるが徹底したルートプレーニングを行ない, 露出歯 根面のルートプレーニング後の歯根面と条件を近いもの にした。

2）歯槽骨の欠損形態について

過去の再付着実験では，煩側歯槽骨を使用し，近遠心 


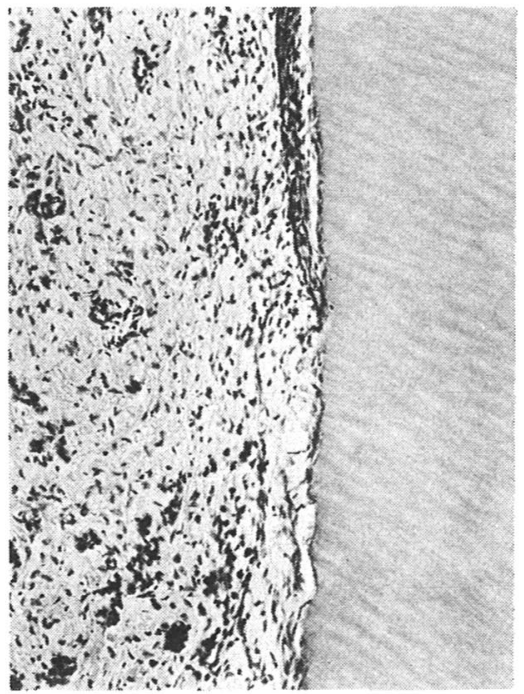

図 $12 \mathrm{~d}$ 図 $12 \mathrm{a}$ の強抗大 上皮付着直下部 $\times 100, \mathrm{H}-\mathrm{E}$ 染色

部に骨壁を残した骨欠損を形成していることが多い。

このような場合, 骨欠損の近遠心幅の広狭が歯周組織 の再生に影響を及ぼしているかもしれないと考えられ る。つまり近遠心幅の狭い骨欠損では, 根尖側からだけ でなく両側の骨壁とその歯根膜からも血液供給および末 分化間葉細胞供給を受け，歯周組織の再生を起こしやす く，近遠心幅の広い骨欠損の中央部では，歯周組織の再 生が起こりにくいと考えられる。

宮下 ${ }^{44)}$ は，骨欠損隅角部ならびに根尖側部に骨再生が 起こりやすいことを報告している。Nyman ${ }^{45)}$ も骨欠損 の近遠心幅の影響を示唆している。

周囲歯周組織から骨欠損部に遊出してくる未分化間葉 細胞の種類, 量, 移動量, 歯周組織再生能力など未知の 点が非常に多いと思われる。

そこで歯周組織の再生に及ぼすこのような複雑な骨の 因子をさけるために, 本実験では煩側と歯間部の歯槽骨 を水平に削除し，骨および歯根膜の影響を根尖側からの 1 面だけとした場合の歯周組織再生能力を調べた。

\section{3）口腔清掃について}

歯周組織の再生を獲得するためには，術後の炎 症 ${ }^{1146)}$ と上皮の根尖側増殖を阻止しなくてはならない47)48)。

その 1 つの方法が術後の適切な口腔清掃であると考え られる。

$\mathrm{Nyman}^{49)}$ は手術領域におけるプラークの有無が歯周 炎の外科的処置の成否を決定寸ると述べ，その後の一連 の研究で手術後の口腔清掃の重要性を確認してき

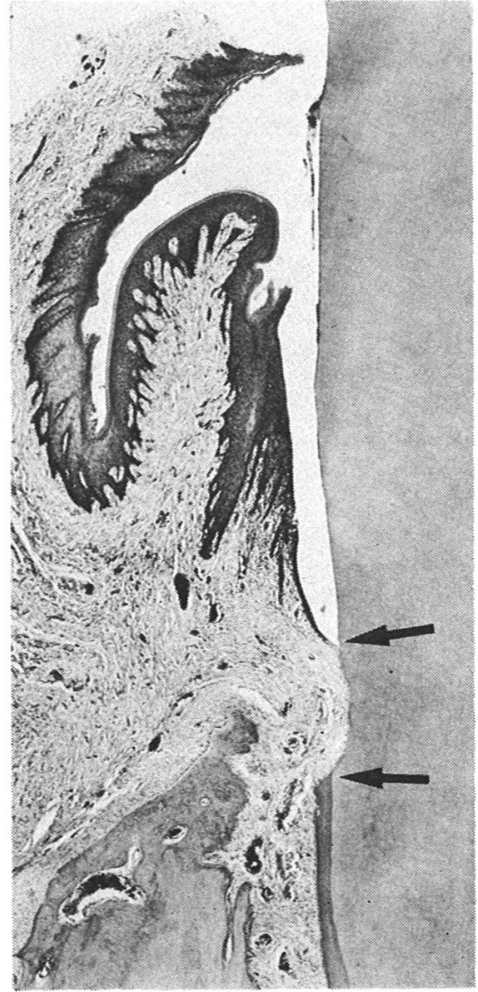

図 13 a $3 \mathrm{~mm}$ 骨削除群前歯 上皮の根尖側増殖の著しい例（11 歯中 8 歯)。この例では, 結合組織性 再付着は $0.5 \mathrm{~mm}$, 上皮の根尖側 増殖 (上の矢印) は $2.5 \mathrm{~mm}$ 認めら れる。歯槽骨頂部は，骨削除断端 (下の矢印) より $0.2 \mathrm{~mm}$ 歯冠則に 位置している。

$\times 10, \mathrm{H}-\mathrm{E}$ 染色

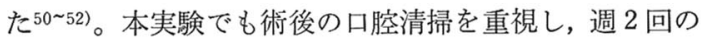
ブラッシングと週 1 回のスケーリング, さらに飲料水と して $0.05 \%$ クロールヘキシジン水溶液を与え, できる かぎり口腔清掃状態を良好に維持した。

Braga ら53)も0.05\%クロールヘキシジン水溶液を飲 料水として与え，機械的な清掃法との併用で, Gingival Index 0 , Plaque Index 1 という口腔清掃状態を獲得し たと述べている。

しかし本実験では前歯部で炎症が認められた。これは 付着歯肉幅が狭く, 唇小帯が高位に付着しているなど口 腔前庭が浅い理由によって，歯肉弁の歯根面への密着が 不良なことと，これらの解剖形態の不良により食物残渣 などがたまりやすく，プラーク，歯石の沈着が起こった ためと思われる。且歯部では歯一歯肉領域の解剖形態は 


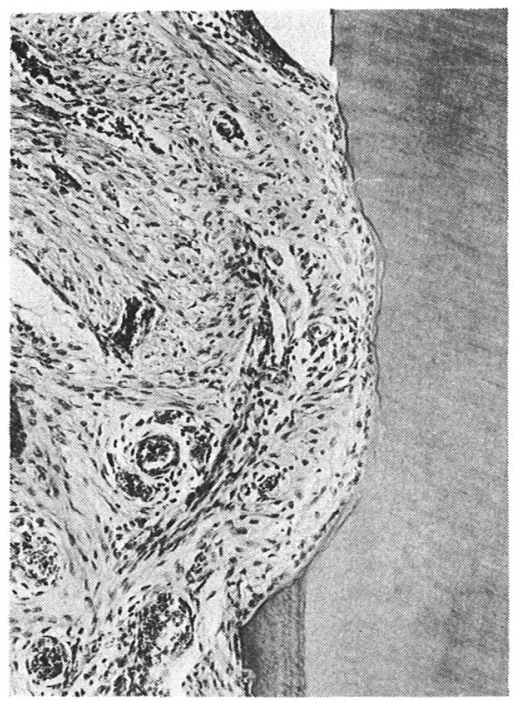

図 $13 \mathrm{~b}$ 図 $13 \mathrm{a}$ の強桩大 $\times 100, \mathrm{H}-\mathrm{E}$ 染色

良好で，プラーク，歯石，炎症はごく軽度認められるに すぎなかった。

\section{2. 骨の再生について}

本実験は術後 10 週目の状態を観察した。骨は一般に骨 整形後又は骨削除後に，一旦骨吸収を起こし 54 57)，その 後骨修復が起こり始め28)57) 58)，3〜4 週目にピークに達 し ${ }^{58)}, 2.5 \sim 3$ 力月後に造骨活性は小さくなると言われて いる1)。したがって 10 週経過した本実験では，骨修復は ほぼ完了したと見ることができると思われる。

今回は煩側と歯間部の歯槽骨を水平に削除したが，一 般に骨壁数が多いほど再生が良いとされており，水平性 骨欠損では骨再生注あまり期待できないと言われている 24) 25) 28) 29)。本実験でも $3 \mathrm{~mm}$ 骨削除群で平均 $0.11 \mathrm{~mm}$, $1.5 \mathrm{~mm}$ 骨削除群で平均 $0.35 \mathrm{~mm}$ の骨吸収が認められ た。

また，骨の再生能力は骨䯣の量によってもきまると言 われており，本実験で用いた煩側歯槽骨は骨㗙が乏しか ったために，骨の再生を起こしにくかったものと思われ る。過去の煩側歯槽骨を用いた骨整形実験でも, 骨吸収 が認められている59) 60061) 56)。

しかし，ある特定の部位，例えば $3 \mathrm{~mm}$ 骨削除群の下 顎では骨の再生が認められることもあった。これは，こ の部位で骨削除断面が広く，骨髄が豊富だったためと思 われる。

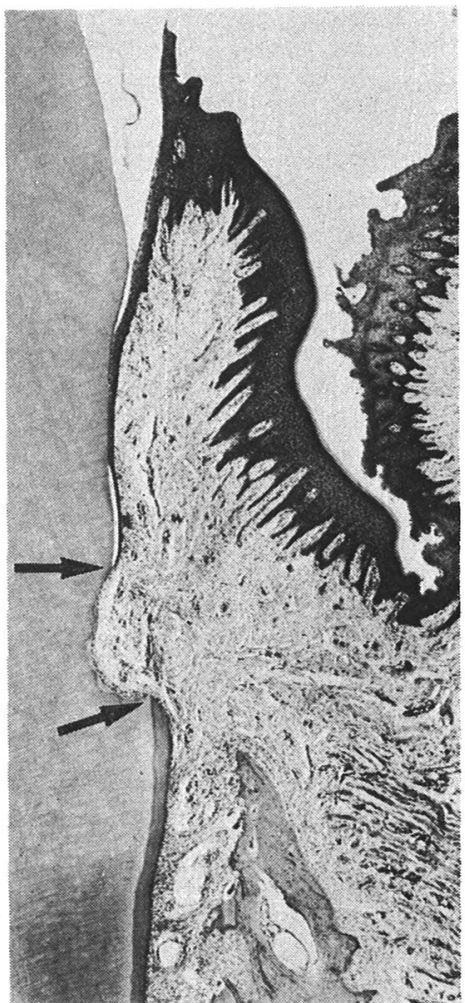

図 $14 \mathrm{a} \quad 1.5 \mathrm{~mm}$ 骨削除群前歯 上皮の根尖側增殖の著しい例 (11 歯 中 7 歯)。この例では結合組織性再 付着は $0.2 \mathrm{~mm}$, 上皮の根尖側増殖 (上の矢印) は $2.5 \mathrm{~mm}$ 認められる。 歯槽骨頂部は，骨削除断端ノッチ (下の矢印) より $0.1 \mathrm{~mm}$ 根尖側に 位置している。

$\times 10, \mathrm{H}-\mathrm{E}$ 染色

3. 結合組織性再付着と新生セメント質の再生につい $\tau$

外科的に露出したセメント質とその付着線維を保存し た時，歯肉側の線維と再結合することによって，上皮の 根尖側増殖を阻止できると言われている 19 23)。

しかし本実験のようにセメント質とその付着線維を除 去した根面では，普通 long junctional epithelium ある いは short junctional epithelium と根面に平行に配列 したコラーダン線維の接合が見られるという2122262)。過 去の実験的歯肉剝離搔爬手術でも，上皮の根尖側増殖を 起こしている例が多く認められている9) 12) 14)15)18222)。

しかし, 本実験の且歯では, $3 \mathrm{~mm}$ 骨削除群で平均 $2.22 \mathrm{~mm}, 1.5 \mathrm{~mm}$ 骨削除群では平均 $1.56 \mathrm{~mm}$, 最長 $3.21 \mathrm{~mm}$ の結合組織性再付着が観察され，上皮の根尖側 


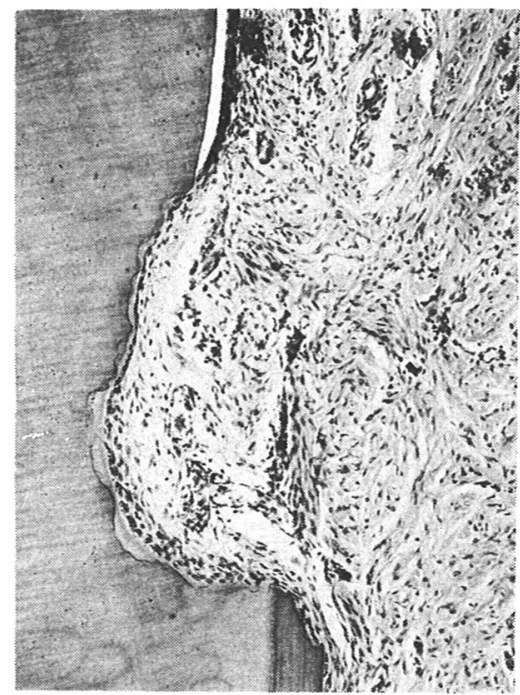

図 $14 \mathrm{~b}$ 図 $14 \mathrm{a}$ の強拡大 $\times 100$, H-E 染色

増殖は $3 \mathrm{~mm}$ 骨削除群で平均 $1.09 \mathrm{~mm}$ (S.D. 0.39), 1.5 $\mathrm{mm}$ 骨削除群で平均 $1.35 \mathrm{~mm}$ (S. D. 0.42) と著しいも のはほとんど認められなかった。

このことより，手術部位にプラークなどの局所刺激が なく，歯肉弁の密着9118)63) を妨害すると思われる因子が なく，さらに食物による外傷がない場合，良好な結合組 織性再付着が得られ，上皮の根尖側増殖は阻止しうるの ではないかと思われる。

結合組織性再付着量については, 過去いろいろな結果 がでているが，本実験のような煩側と歯間部の骨を水平 に削除した骨欠損形態で再付着量を計測したものはない と思われる。

頓側歯槽骨の骨欠損で近遠心部に骨壁を持つもので は, Skillen ら ${ }^{30)}$ は $2 \mathrm{~mm}$ 程度の, Wilderman ら ${ }^{31)}$ は平 均 $2.1 \mathrm{~mm}$ の, Marfino ら ${ }^{32)}$ は $1.5 \mathrm{~mm}$ の, Sugarman ${ }^{33)}$ は最長 $3.2 \mathrm{~mm}$ の再付着を報告している。また, 伊藤 ${ }^{10)}$ は骨頂部を 3〜 $5 \mathrm{~mm}$ 削除した時, 上皮の根尖側増殖は $1.3 \mathrm{~mm}$ 以下であり, Hiatt ら ${ }^{11)}$ は骨頂部を $8 \mathrm{~mm}$ 削除 しても上皮の根尖側増殖は観察されなかったと報告して いる。

以上のように近遠心部の骨に歯肉弁が保持される場 合, 再付着量はまちまちであるように思われる。

しかし，近遠心部に骨壁を持たない骨欠損の場合には， 本実験の最長值である $3.2 \mathrm{~mm}$ 以下の結合組織性再付着 しか得られないことも考えられる。しかし，コントロー ル群の骨頂上の結合組織性付着の長さの平均 $0.67 \mathrm{~mm}$

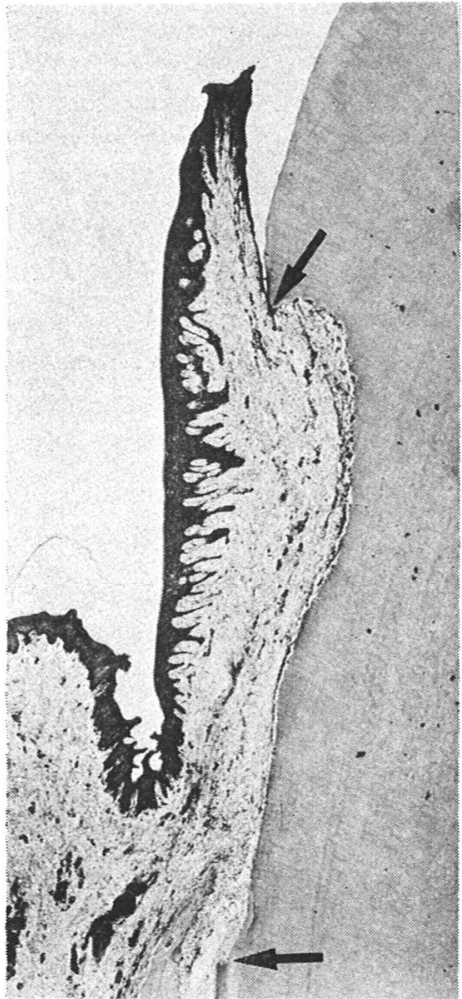

図 $153 \mathrm{~mm}$ および $1.5 \mathrm{~mm}$ 骨 削除群前歯

上皮の根尖側増殖の少ない例 (22 歯中 7 歯)。この例では結合組 織性再付着は $2.91 \mathrm{~mm}$, 上皮の根 尖側増 (上の矢印) は $1.3 \mathrm{~mm}$ 認 められる。歯槽骨頂部は，骨削除 断端ノッチ（下の矢印）より 0.4 $\mathrm{mm}$ 歯冠側に位置している。 $\times 10, \mathrm{H}-\mathrm{E}$ 染色

と比較すると, 本実験の条件でも実験的歯肉剝離搔爬手 術後にはかなり結合組織性再付着が獲得されることが確 認された。

$3 \mathrm{~mm}$ 骨削除群臼歯と $1.5 \mathrm{~mm}$ 骨削除群臼歯との結合 組織性再付着の長さの平均の差は $1.5 \mathrm{~mm}$ の骨削除量の 差にもかかわらず, 実際の付着の長さの差 は平均 0.56 mm でしかなかった。さらに骨頂上の結合組織性再付着 量を考えると, $3 \mathrm{~mm}$ 骨削除群で $2.29 \mathrm{~mm}, 1.5 \mathrm{~mm}$ 骨 削除群で $1.98 \mathrm{~mm}$ と両群の差は $0.32 \mathrm{~mm}$ とさらに小さ くなり，歯槽骨の高さが結合組織性再付着に何らかの影 響を与えていることを示唆していると考えられる。

再生された新生セメント質の長さは, $3 \mathrm{~mm}$ 骨削除群 臼歯で平均 $1.06 \mathrm{~mm}$ (S.D. 0.54), $1.5 \mathrm{~mm}$ 骨削除群臼歯 
表 4 組織学的計測値

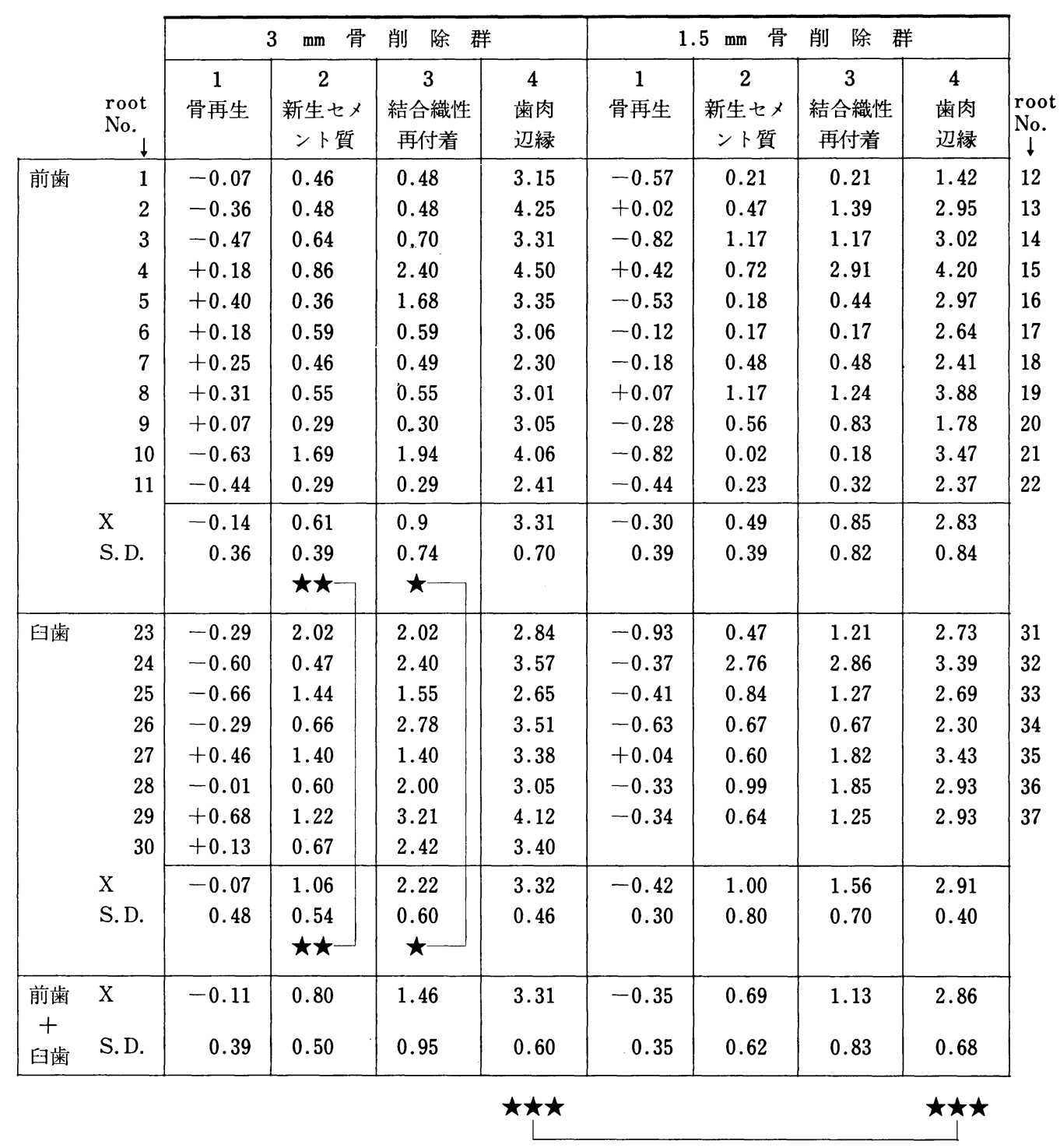

$\star$ 有意差あり $\mathrm{P}<0.05$

$\star \star 、 \star \star \star$ 有意差あり $\mathrm{P}<0.05$

で平均 $1.00 \mathrm{~mm}$ (S.D. 0.8) だった。新生セメント質の 添加がみられる歯根面には, 多くの歯で表在性の吸収が 認められた。この歯根面の吸収は, 先人12) 13131)62)の実験 でも観察されており, 新生セメント質添加前の現象であ ると言われている。

過去の実験を参考にすると, 4 週目頃に新生セメント 質は観察されはじめ, その後長期間に渡って持続的に添 加される12 14)64) ものと考えられるので, 本実験の 10 週
目の状態ではセメント質は治癒過程にあり，今後治療の 進行とともに, さらに新生セメント質が添加されるもの と思われる。

$3 \mathrm{~mm}$ 骨削除群臼歯の 2 歯では良好なセメント質の再 生が認められた。この理由はわからないが，その場合歯 根面の表在性の吸収は著明ではなく,すみやかに新生セ メント質が再生されたようである。

セメント質の添加量については, Diem ${ }^{16)}$ が術後 91 日 


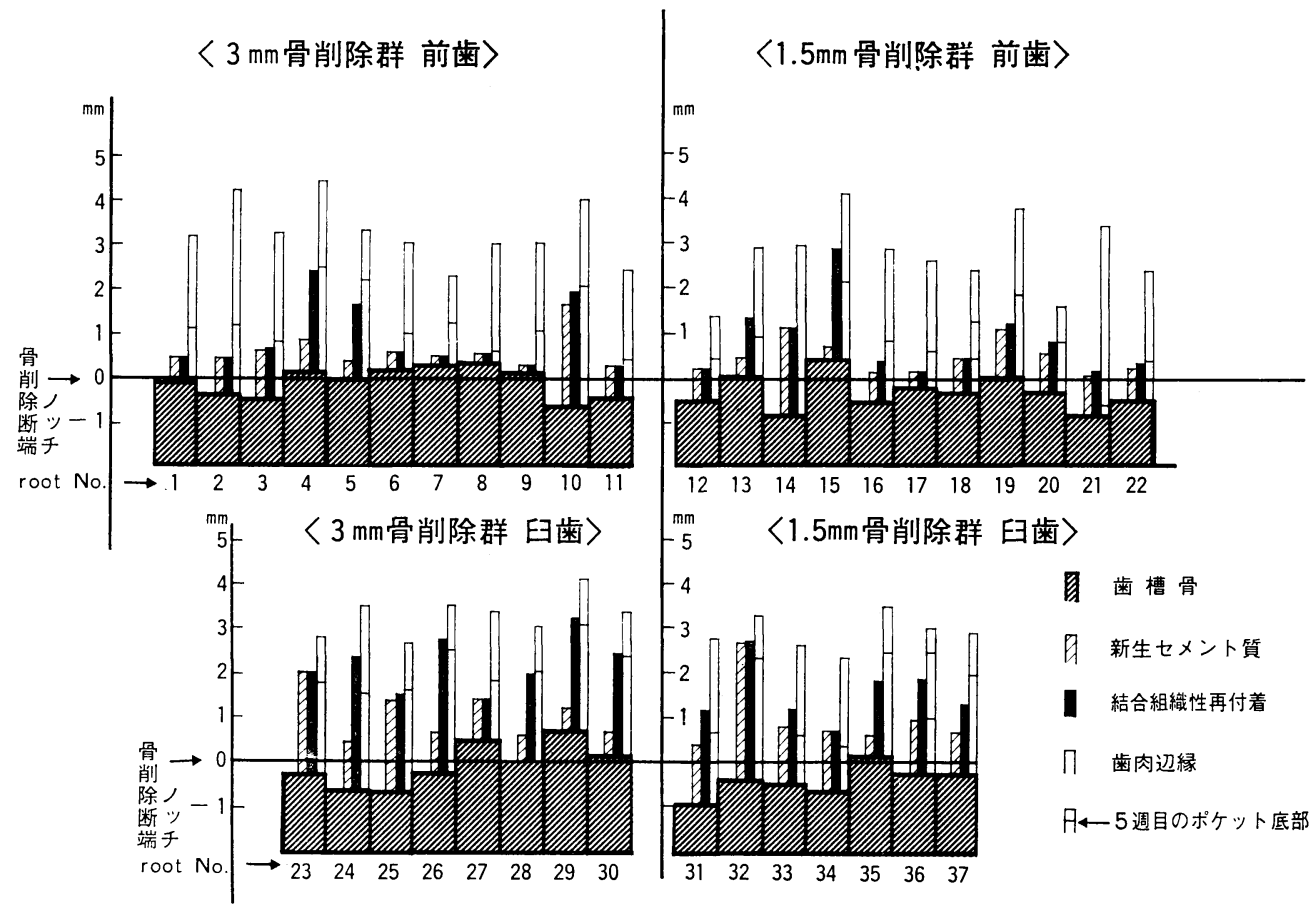

図 16 組織学的計測值 (表 4 の図式化)

目の生活歯で平均 $1.3 \mathrm{~mm}$, 失活根充歯で平均 $1.75 \mathrm{~mm}$ の添加を観察している。Diem の結果と比較して本実験 の結果の值が小さいのは, 観察期間が短いこと, 骨欠損 の近遠心に骨壁を持たなかったことなどが考えられる。

新生セメント質の添加部位については，本実験では根 尖側ほど厚く, 歯冠側に行くに従いその厚みを減少し た。またノッチ，溝などの凹部さらに凹部の隅角部に添 加されやすく，厚みをもって形成される傾向があった。 これらの所見は先人の実験7)14)65) とほぼ一致していた。

一方, 10 週目でも新生セメント質の添加が認められ ない部分が，歯冠側部にかなりみられた。新生セメント 質の添加を伴わない結合組織性再付着部では, 線維芽細 胞様細胞が歯根面に密着あるいはコラーゲン線維が根面 に接合しており，このような部で上皮の根尖側増殖は停 止しているようだった。

Persson ${ }^{12)}$, Stahl ${ }^{62)}$, Ellegaard ら ${ }^{66)}$ は, 新生セメント質 の再生と線維の埋入がなくても, 歯根面と結合組織の接 合の状態で上皮の根尖側増殖を阻止することができると 述べている。本実験の結果でも，上皮の根尖側増殖は, 治癒過程中の幼若結合組織の接合でも阻止しうるものと 思われる。
線維の配列は, 10 週目の状態でも根面にほぼ平行であ った。しかし, 治癒経過とともに機能的配列を示すよう になると言われている3)7)17)。本実験でも, 骨, 新生セメ ント質の再生が認められる根尖側部では, わずかではあ るが線維の機能的配列が認められるものもあった。

しかし, 歯根面に新生セメント質が再生され, そのセ メント質に歯肉線維が機能的配列をもって埋入するよう になるためには，本実験の結果から考えると相当長い期 間を必要とするものと思われる。

一方, プラークなどの局所刺激による炎症，歯肉弁の 密着を妨害する因子が存在すると考えられる前歯では, 臼歯のように良好な結合組織性再付着が得られなかっ た。このような時, 根尖側部の新生セメント質の再生部 分で上皮の根尖側増殖は停止しているようであった。

手術後の上皮の根尖側増殖の原因は明らかではない。 考えられる因子としては, 歯肉辺縁部に存在するプラー クが炎症を導き, その炎症が治癒過程中の歯一歯肉界面 に速やかな根尖側増殖を導いたものと思われる。また, 新生セメント質の添加を伴わない結合組織の接合という 治癒は，炎症に対する防御が弱いのかもしれない67)。 また，口腔前庭が浅い，付着歯肉幅が狭い，唇小帯が 
高位に付着しているなどの歯一歯肉解剖形態の不良によ る歯肉弁の歯根面への密着の不良が, 上皮の根尖側増殖 を起こしたとも考えられる。

\section{4. 再付着の可能性について}

歯槽骨, 歯根膜断端部から歯冠側に何 $\mathrm{mm}$ 位 結 合 組 織性再付着が期待できると考えてよいのか。歯根面がた とえ生物学的に無害であったとしても, 無血管部位であ る歯根面に無制限に歯肉弁を再付着させることは困難で あると考えられる。Ruben ら ${ }^{68)}$ は 1 1.5 mm が限度で あると述べている。Sullivan ら 69 も F.G.G.による広く て深い歯肉退縮に対する処置では, 根尖側部に 1 2 $\mathrm{mm}$ の角化組織を形成するにすぎないと述べている。

本実験の白歯では, $3 \mathrm{~mm}$ 骨削除群で平均 $2.22 \mathrm{~mm}$, $1.5 \mathrm{~mm}$ 骨削除群で平均 $1.56 \mathrm{~mm}$ の結合組織性再付着 が得られた。一般に歯冠側部には新生セメント質の再生 を伴わない結合組織の接着がかなり認められたが，この 結合組織の接着は, 歯肉弁中の線維芽細胞および結合組 織中の血管周囲で増殖した線維芽細胞が速やかに歯根面 に付着して得られたものと思われる。このような結合組 織の接着は骨の再生, セメント質の再生の可能性を残し ているという点で重要である。

本実験で新生セメント質が根尖側部に平均 $1 \mathrm{~mm}$ 弱認 められ，またより根尖側ほどその添加量が多いことを考 えると，セメント芽細胞は根尖側の歯根膜から遊出ある いは，根尖側寄りからセメント芽細胞化してくることを 示唆し，これは傷害部に遊出してくる細胞が歯根膜由来 細胞であると歯根膜を形成するという過去の実験70 72) と一致しているように思われる。しかし，根尖側一方向か らのセメント芽細胞の拡散およびセメント芽細胞化活性 は緩慢と考えられ，10 週の状態でも長さにして歯冠側に 平均 $1 \mathrm{~m} \mathrm{~m}$ 弱の新生セメント質が添加されているにすぎ ず, その添加量も多くなかった。新生セメント質の添加 量には限界があるのかもしれない。

骨の再生は，骨膜および骨髄からの骨芽細胞によると 言われている。本実験のような煩側歯槽骨では，骨髄が 少ないためその造骨活性は弱いものと思われ，通常は骨 吸収が認められた。しかし， $3 \mathrm{~mm}$ 骨削除群の下顎で再 生がよかったのは，骨断端の厚みがあり骨髄が豊富だっ たために，骨芽細胞も豊富で造骨活性を高く示したため と思われる。

以上のような未分化間葉細胞が，再付着を積極的に行 なうのであるが, プラークなどによる炎症, 歯肉弁の密 着の不良などの悪因子が働くと，これらの活性は敏感に
影響を受け，再付着に失敗するものと思われる。

\section{V. 結 論}

実験的歯肉剝離搔爬手術後の粘膜骨膜弁の結合組織性 再付着量を調べるために，猿を用いて次の実験を行なっ た。 2 頭の $\frac{5 \text { ケ } 5}{5 \sim 5}$ の 40 歯部を用いて, 骨頂部より $3 \mathrm{~mm}$ および $1.5 \mathrm{~mm}$ 煩側と歯間部の歯槽骨を水平に削除し た。歯根面をルートプレーニングした後, 粘膜骨膜弁を 元の位置へ戻して縫合し, 術後 10 週目の状態を組織学的 に観察した。なお術後口腔清掃をできるかぎり良好に保 ち, 炎症を可能な限り抑制した。

その結果，次のような知見を得た。

1）新生セメント質が明瞭に見られない結合組織の接 着の状態でも，上皮の根尖側増殖は阻止されていた。

2) 臼歯の結合組織性再付着の長さ（骨削除底部加ら 上皮付着最根尖部までの長さ) は, $3 \mathrm{~mm}$ 骨削除群で平 均 $2.22 \mathrm{~mm}$ (S.D. 0.60), $1.5 \mathrm{~mm}$ 骨削除群で平均 1.56 mm (S.D. 0.70) だった。

3） 歯の新生セメント質の長さは， $3 \mathrm{~mm}$ 骨削除群 で平均 $1.06 \mathrm{~mm}$ (S.D. 0.54), $1.5 \mathrm{~mm}$ 骨削除群で平均 $1.00 \mathrm{~mm}$ (S.D. 0.80) だった。

4）前歯の 22 歯中 15 歯では, 著しい上皮の根尖側増 殖が見られ，根尖側寄りの新生セメント質が添加されて いる部分で，その増殖は停止していた。

5）前歯の結合組織性再付着の長さは, $3 \mathrm{~mm}$ 骨削除 群で平均 $0.90 \mathrm{~mm}$ (S.D. 0.74), $1.5 \mathrm{~mm}$ 骨削除群で平 均 $0.85 \mathrm{~mm}$ (S.D. 0.82) だった。

6) 前歯の新生セメント質の長さは, $3 \mathrm{~mm}$ 骨削除群 で平均 $0.61 \mathrm{~mm}$ (S.D. 0.39), $1.5 \mathrm{~mm}$ 骨削除群で平均 $0.49 \mathrm{~mm}$ (S.D. 0.39) だった。

7）再生された歯槽骨の長さは，前歯と臼歯の両者に ついてみると, $3 \mathrm{~mm}$ 骨削除群で平均一 $0.11 \mathrm{~mm}$ (S.D. 0.39), $1.5 \mathrm{~mm}$ 骨削除群で平均一 $0.35 \mathrm{~mm}$ (S.D. 0.35) だった。

8）骨削除底部から歯肉辺縁までの長さは，前歯と白 歯の両者についてみると, $3 \mathrm{~mm}$ 骨削除群で平均 3.31 $\mathrm{mm}$ (S.D. 0.6), $1.5 \mathrm{~mm}$ 骨削除群で $2.86 \mathrm{~mm}$ (S.D. 0.68) だった。

9）コントロール群 $\frac{7 \mid 7}{7 \mid 7}$ の 8 歯の骨頂上の結合組織 性付着の長さの平均は $0.67 \mathrm{~mm}$ (S.D. 0.17), 骨頂部か ら歯肉辺縁までの長さの平均は, $2.08 \mathrm{~mm}$ (S.D. 0.39) だった。 
謝辞 稿を終るにのぞみ, 御指導, 御校閲をいただきました 木下四郎教授に謹しんで感謝の意を表します。また懇切丁寧な 御指導, 御教授をいただきました東京医科歯科大学口腔病理学 教室石川梧朗教授, 高木実助教授, 本教室の野口俊英講師に深 く感謝の意を表します。また本研究の実施に当たり種々お世話 になりました本学第 2 歯科保存学教室員各位に心から御礼申し 上げます。

\section{文献}

1) Ramfjord, S. : Experimental periodontal reattachment in rhesus monkeys. J. Periodontol., 22 : 67-77, 1951.

2) Morris, M.L. : Healing of naturally occurring periodontal pockets about vital human teeth.

J. periodontol., 26 : 285-292, 1955.

3）中久木大見，歯肉剝離創の治癒に関する実験的研 究 I. 病理組織学的所見について. 口科誌, 15 : 325-338, 1966.

4) Yukna, R.A. : A Clinical and histologic study of healing following the Excisional New Attachment Procedure in rhesus monkeys. : J. Periodontol., 47 : 701-709, 1976.

5) Caton, J. and Nyman, S. : Histometric evaluation of periodontal surgery I. The modified widman flap procedure. J. Clin. periodontol., $7: 212-223,1980$.

6) Caton, J., Nyman, S. and Zander, H. : Histometric evaluation of periodontal surgery II. Connective tissue attachment levels after four regenerative procedures. J. Clin. Periodontol., 7 : 224-231, 1980.

7) Morris, M.L. : The reattachment of human periodontal tissues following surgical detachment : A clinical and histological study. J. periodontol., $24: 220-228,1953$.

8) Morris, M.L. : Healing of human periodontal tissues following surgical detachment from non-vital teeth. J. Periodontol.,28:222-238, 1957.

9) Morris, M.L. : Healing of human periodontal tissues following surgical detachment from vital teeth: The position of the epithelial attachment. J. Periodontol., 32 : 108-112, 1961.

10）伊藤秀夫：改良歯肉剝離搔爬手術について 実験
的並びに臨床的研究. 口科誌, $5: 438-452,1956$.

11）柳田藤吉, 土谷裕彦 : 失活歯の歯肉剝離創の治癒 に関する実験的研究，口科誌， $7: 235-242,1958$.

12) Persson, P.A.: The regeneration of the marginal periodontium after flap operation An experimental study on dogs. Acta Odont. Scand., $20: 43-80,1962$.

13) Hiatt, W.H., Stallard, R.E., Butler, E.D. and Badgett, B. : Repair following mucoperiosteal flap surgery with full gingival retention. J. Periodontol., 39 : 11-16, 1968.

14) Listgarten, M.A. : Electron microscopic study of the junction between surgically denuded root surfaces and regenerated periodontal tissues. J. Periodont. Res., $7: 68-90,1972$.

15) Frank, R., Donno, G.F., Cimasoni, G. and Matter, J. : Ultrastructural study of epithelial and connective gingival reattachment in man. J. Periodontol., 45 : 626-635, 1974.

16) Diem, C.R., Bowers, G.M., Ferrigno, P.D. and Fedi, P.F. Jr. : Regeneration of the attachment apparatus on pulpless teeth denuded of cementum in the rhesus monkey. J. Periodontol., $45: 18-22$, 1974.

17）高山文晴 : 実験的セメント質削除後のイヌ歯周組 織の再付着について一有髄歯と無髄歯の比較一. 日歯周誌, $22: 11-37,1980$.

18) Lahiffe, B. J., Caffesse, R.G. and Nasjleti, C.E. : Healing of periodontal flaps following use of MBR 4197 (Flucrylate) in rhesus monkeys A clinical and histological evaluation. J. Periodontol., 49 : 635-645, 1978.

19) Kohler, C.A. and Ramfjord, S.P. : Healing of Gingival mucoperiosteal flaps. Oral Surg., 13 : 89-103, 1960.

20) Levine, H.L. and Stahl, S.S. : Repair following periodontal flap surgery with the retention of gingival fibers., J. Periodontol., 43 : 99-103, 1972 .

21) Stahl, S.S. : The nature of healthy and diseased root surfaces. J. Periodontol., $46: 156-161$, 1975.

22) Stahl, S.S. : Healing following "simulated fiber retention" procedures in rats. J. Periodontol., 
$48: 67-73,1977$.

23) Stahl, S.S. : Repair potential of the soft tissue-root interface. J. Periodontol., $48: 545-552$, 1977.

24) Prichard, J. : The infrabony technique as a predictable procedure. J. Periodontol., 28 : 202-216, 1957.

25) Pature, B. and Glickman, I. : Clinical and roentgenographic evaluation of the posttreatment healing of infrabony pockets. J. Periodontol., 33 : 164-171, 1962.

26) Ellegaard, B. and Löe, H. : New attachment of periodontal tissues after treatment of intrabony lesions. J. Periodontol., 42 : 648-652, 1971.

27) Ellegaard, B., Karring, T. and Löe, H. : New periodontal attachment procedure based on retardation of epithelial migration. J. Clin. Periodontol., 1 : 75-88, 1974.

28）小林英和：サルの歯槽骨にいろいろな欠損を与え た場合の修復過程について. 口病誌, $38: 404-$ 423, 1971.

29) Patterson, R.L., Collings, C.K. and Zimmerman, E.R. : Autogenous implants in the alveolar process of the dog with induced periodontitis. Periodontics, $2: 80-86,1975$.

30) Skillen, W.G. and Lundquist, G.R. : An experimental study of periodontal membrane reattachment in healthy and pathologic tissues. J. Am. Dent. Assoc., 24 : 175-185, 1937.

31) Wilderman, M.N. and Wentz, F.M. : Repair of a dento gingival defect with a pedicle flap.

J. Periodontol., 36 : 218-231, 1965.

32) Marfino, N.R., Orban, B.J., and Wentz, F.M.: Repair of the dento-gingival junction following surgical intervention. J. Periodontol., 30 : 180-190, 1959.

33) Sugarman, E. : A clinical and histological study of the attachment of grafted tissue to bone and teeth. J. Periodontol., 40 : 381-387, 1969.

34) Tavtigian, R. : The height of the facial radicular alveolar crest following apically positio ned flap operations. J. Periodontol., 41 : 412418, 1970.

35) Armitage, G.C. : Alterations in exposed human cementum. J. Western Society of Periodontol., $25: 60-68,1977$.

36) Benson, L.A. : A study of a pathologic condition in exposed cementum. O.S., O.M. and O.P., 16 : 1137-1144, 1963.

37) Armitage, G.C. and Christie, T. M. : Structural changes in exposed human cementum 1. Light microscopic observations. J. Periodontal Res., $8: 343-355,1973$.

38) Bigarre, C. and Yardin, M. : Demonstration of lipids in the pathologic granules in cementum and dentin in periodontal disease. J. Clin. Periodontol., 4 : 210-213, 1977.

39) Selvig, K.A. and Hals, E. : Periodontally diseaed cementum studied by correlated microradiography, electron probe analysis and electron microscopy. J. Periodontal Res., $12: 419$ 429, 1977.

40) Aleo, J.J., DeRenzis, F.A., Farber, P.A. and Varboncoeur, A.P. : The presence and biologic activity of cementum-bound endotoxin. J. Periodontol., $45: 672-675,1974$.

41) Fine, D.H., Morris, M.L., Taback. L. and Cole, J.D. : Preliminary characterization of material eluted from the roots of periodontally diseased teeth. J. Periodontal Res., $15:$ 10-19, 1980.

42) Aleo. J.J., DeRenzis, F.A. and Farber, P.A. : In vitro attachment of human gingival fibroblasts to root surfaces. J. Periodontol., $46: 639$ $645,1975$.

43) Jones, W.A. and $\mathrm{O}^{\prime}$ Leary, T.J. : The effectiveness of in vivo root planing in removing bacterial endotoxin from the roots of periodontally involved teeth. J. Periodontol., $49: 337-342$, 1978.

44）宮下元 : 露出セメント質が歯周組織の治癒に与え る影響 特に歯槽骨の修復について. 日歯周誌, $18: 225-244,1976$.

45) Nyman, S. and Karring, T. : Regeneration of surgically removed buccal alveolar bone in dogs. J. Periodontal Res., 14 : 86-92, 1979.

46) Ellggaard, B., Karring, T., Davies, R. and Löe, H. : New attachment after treatment of intrabony defects in monkeys. J. Periodontol., 45 : 
368-377, 1974.

47) Björn, H. : Experimental studies on reattachment. Dental Practitioner, 11 : 351-354, 1961.

48) Björn. H., Hollender, L. and Lindhe, J. : Tissue regeneration in patients with periodontal disease. Odontologisk Revy, $16: 317-326,1965$.

49) Nyman, S., Rosling, B. and Lindhe, J. : Effect of professional tooth cleaning on healing after periodontal surgery. J. Clin. Periodontol., 2 : 80-86, 1975.

50) Rosling, B., Nyman, S. and Lindhe, J. : The effect of systematic plaque control on bone regeneration in infrabony pockets. J. Clin. Periodontol., $3:$ :38-53, 1976.

51) Rosling, B., Nyman, S., Lindhe, J. and Jern, B. : The healing potential of the periodontal tissues following different techniques of periodontal surgery in plaque-free dentition. J. Clin. Periodontol., $3: 233-250,1976$.

52) Polson, A.M. and Heijl, L.C.: Osseous repair in infrabony periodontal defects. J. Clin. Periodontol., $5:$ 13-23, 1978.

53) Braga, A.M. and Squire, C.A. : Ultrastructure of regenerating junctional epithelium in the monkey. J. Periodontol., $51: 386-392,1980$.

54) Lobene, R. and Glickman, I. : The Response of alveolar bone to grinding with rotary diamond stones report one. J. Periodontol., 34 : 105-119, 1963.

55) Wilderman, M. N. : Repair aftar a periosteal retention procedure. J. Periodontol., $34: 487$ 503, 1963.

56) Wilderman, M.N., Pennel, B.M., King, K. and Barron, J. M. : Histogenesis of repair following osseous surgery. J. Periodontol., $41: 551-565$, 1970.

57）小林英和，宮下元，遠藤信武，横田誠：鉛塩注射 による硬組織内時刻描記法を応用した歯槽骨の修 復過程に関する研究. 口病誌, $39: 779-786$. 1972.

58) Wilderman, M.N., Wentz, F.M. and Orban, B.J. : Histogenesis of repair after mucogingival surgery. J. Periodontol., 31 : 283-299, 1960.

59) Pennel, B.M., King, K.O., Wilderman, M.N. and Barron. J.M. : Repair of the alveolar process following osseous surgery. J. Periodontol., 38, 426-431, 1967.

60) Friedman, N. and Levine, H.L. : Mucogingival surgery, current status. J. Periodontol., $35: 5$ 21, 1964.

61) Wood, D.L., Hoag, P.M., Donnenfeld, O.W. and Rosenfeld, L.D. : Alveolar crest reduction following full and partial thickness flaps. J. Periodontol., 43 : 141-144, 1972.

62) Stahl, S.S., Slavkin, H.C., Yamada, L. and Levine, S. : Speculation about gingival repair. J. Periodontol., 43 : 395-402, 1972.

63) Caffesse, R.G., Ramfjord, S.P. and Nasjleti, C.E. : Reverse bevel periodontal flap in monkeys. J. Periodontol., 39 : 219-235, 1968.

64) Tonna, E.A. : Factors (asing) affecting bone and cementum. J. Periodontol., $47: 267-280$, 1976.

65) Morris, M.L. and Thompson, R.H.: Healing of human periodontal tissues following surgical detachment, factors related to the deposition of new cementum on dentin. Periodontics, 1 : 189-195, 1963.

66) Ellegaard, B., Karring, T. and Löe, H. : Retardation of epithelial migration in new attachments attempts in intrabony defects in monkeys. J. Clin. Periodontol., 3 : 23-37, 1976.

67) Stahl, S.S. : Repair or regeneration following periodontal therapy? J. Clin. Periodontol., 6 : 389-396, 1979.

68) Ruben, M.P. Kon, S., Goldman, H.M., Alpha, K. and Bloom, A.A. : Complications of the healing process after periodontal surgery. J. Periodontol., 43 : 339-346, 1972.

69) Sullivan, H.C. and Atkins, J.H. : Free autogenous gingival grafts. III. Utilization of grafts in the treatment of gingival recession. Periodontics, $6: 152-160,1968$.

70) Melcher : Repair of wounds in the periodontium of the rat. Influence of periodontal ligament on osteogenesis. Archs Oral Biol., 15 : 11831204, 1970.

71) Line, S.E., Polson, A.M. and Zander, H.A. : 
Relationship between periodontal injury, selective cell repopulation and ankylosis. J. Periodontol., $45:$ 725-730, 1974.

72) Karring, T., Nyman, S., and Lindhe, J.: Healing following implantation of periodontitis affected roots into bone tissue. J. Clin. Periodontol., 7 : 96-105, 1980.

73) Bowen W.H. : Advances in Oral Biology. New York \& London., Academic Press, 3 : 190, 1968. 